\title{
Advanced m-CHP fuel cell system based on a novel bio- ethanol fluidized bed membrane reformer
}

\author{
Jose Luis Viviente, ${ }^{1, *}$, Jon Meléndez ${ }^{1,2}$, David Alfredo Pacheco Tanaka ${ }^{1}$, Fausto \\ Gallucci $^{3}$, Vincenzo Spallina ${ }^{3}$, Giampaolo. Manzolini ${ }^{4}$, Stefano Foresti ${ }^{4}$, Vincenzo \\ Palma $^{5}$, Concetta Ruocco ${ }^{5}$, Leonardo Roses ${ }^{6}$ \\ ${ }^{1}$ TECNALIA, Energy and Environment Division, Mikeletegi Pasealekua 2, 20009, San Sebastian- \\ Donostia, Spain \\ 2 Chemical Engineering and Environmental Department, University of the Basque Country \\ UPV/EHU, C/ Alameda Urquijo s/n, 48013 Bilbao, Spain \\ 3 Chemical Process Intensification, Department of Chemical Engineering and Chemistry, \\ Eindhoven University of Technology, P.O. Box 513, 5612 AZ Eindhoven, The Netherlands \\ ${ }^{4}$ Politecnico di Milano, Deparment of Energy, via Lambruschini 4, 20156 Milano, Italy \\ ${ }^{5}$ Universita degli Studi di Salerno, Department of Industrial Engineering, via Giovanni Paolo II \\ 132, 84084 Fisciano (SA), Italy \\ ${ }^{6}$ HyGear B.V., P.O. Box 5280, 6802 EG Arnhem, The Netherlands
}

*Author to whom correspondence should be addressed: joseluis.viviente@tecnalia.com

\begin{abstract}
Distributed power generation via Micro Combined Heat and Power (m-CHP) systems, has been proven to over-come disadvantages of centralized generation since it can give savings in terms of Primary Energy consumption and energy costs.

The FluidCELL FCH JU/FP7 project aims at providing the Proof of Concept of an advanced high performance, cost effective bio-ethanol m-CHP cogeneration Fuel Cell system for decentralized offgrid applications by end of 2017. The main idea of FluidCELL is to develop a new bio-ethanol membrane reformer for pure hydrogen production $\left(3.2 \mathrm{Nm}^{3} / \mathrm{h}\right)$ based on Membrane Reactors in order to intensify the process of hydrogen production through the integration of reforming and purification in one single unit. The novel reactor will be more efficient than the state-of-the-art technology due to an optimal design aimed at circumventing mass and heat transfer resistances. Moreover, the design and optimization of the subcomponents for the BoP will be also addressed. Particular attention will be devoted to the optimized thermal integration that will improve the overall efficiency of the system at $>90 \%$ and reducing the cost due to low temperature reforming. The main results obtained until now in terms of performance of the catalysts, membranes and the membrane reactors will be presented in this work.
\end{abstract}

Keywords: Palladium membrane, fluidized membrane reactor, Hydrogen production, micro-CHP system, PEM fuel cell, bio-ethanol SMR

\section{Introduction}

According to the Future of Rural Energy in Europe (FREE) initiative [1], rural areas represent 90\% of all territory in the EU-27 and over $50 \%$ of the population (around $46 \%$ of population in the world [2]). They generate $43 \%$ of Europe's gross value and support $55 \%$ of all employment. From these, there are at least 30 million homes and businesses which will probably never have access to the natural gas grid and instead largely rely on high carbon intensive energy sources. Paradoxically, rural communities have a higher carbon footprint per person than they need to and often higher than 
their urban compatriots. This is, among others, because of the fuel sources, as well as the inefficient conventional technologies used.

Major concerns on anthropogenic $\mathrm{CO}_{2}$ emissions and related greenhouse effect have pushed several governments to support greenhouse gas emission reduction policies. EU, for example, set a very high target for reduction of greenhouse gas emissions by $40 \%$ compared to 1990 levels within 2030 (at least $80 \%$ by 2050 ), together with an increase by $27 \%$ of energy efficiency and renewables share in the energy consumption [3]. Stationary fuel cells offer a clean and efficient source of electricity in systems ranging from $1 \mathrm{~kW}$ up to $1 \mathrm{MW}$ or more [4]. With an appropriate fuel processing technology, fuel cells are able to tap into established or accessible sources of fuels such as natural gas but also various other fuels including biofuels and bio-gases.

Distributed power generation via Micro Combined Heat and Power (m-CHP) systems (cogeneration unit with a maximum capacity below $50 \mathrm{kWe}$ [5]), has been proven to over-come disadvantages of centralized generation since it can give savings in terms of Primary Energy consumption and energy cost (residential applications are about $30 \%$ of the total consumption) and $\mathrm{CO}_{2}$ emission reduction $[4,6,7,8,9]$. The main advantage is that m-CHP systems are able to recover and use the heat that in centralized systems is often lost. In a distributed generation scenario, fuel cells systems could lead to particularly high efficiencies (electrical efficiency up to $60 \%$, first law efficiency in cogeneration of more than 90\%), thereby attaining considerable primary energy saving whilst avoiding transmission losses. However, wide exploitation of these systems is still hindered by high costs and low reliability due to the complexity of the system.

Hydrogen availability is the most critical issue because it must be produced in-situ starting from the available fuel through a fuel processor upstream the fuel cell stack. However, at the moment hydrogen is still being produced by fossil fuel conversion, mainly, by reforming or gasification. When looking to remote installations, far away from natural gas grids and/or electrical grids, hydrogen can be produced from bio-renewable feedstocks. Among the various feedstocks, bioethanol is one of the preferred renewable sources for hydrogen production thanks to its unique features. Its hydrogen capacity is relatively high; it is easier to handle than hydrogen gas, being liquid and non-toxic; and even better, it is produced at global scale [10].

In this work, an overview of the main results achieved in the frame of the FluidCELL project is presented. The aim of the FluidCELL project is the proof of concept of an advanced high performance, cost effective bio-ethanol micro Combined Heat and Power cogeneration Fuel Cell system for decentralized off-grid applications. The main idea of FluidCELL is to develop a new bio-ethanol membrane reformer for pure hydrogen production $\left(3.2 \mathrm{Nm}^{3} / \mathrm{h}\right)$ based on Membrane Reactors in order to intensify the process of hydrogen production through the integration of reforming and purification in one single unit. The technology of membrane reactors has been developed in the last decades and it has demonstrated a high degree of process intensification where the combination of a membrane based separation and a catalytic chemical reaction in one unit take $[11,12,13,14,1516,17,18,19,20]$ place. In equilibrium limited reaction systems such as in fuel reforming or dehydrogenations, the selective separation of a product of the reaction (i.e. $\mathrm{H}_{2}$ ), implies a displacement of the thermodynamic equilibrium towards the products, thus achieving higher fuel conversions and direct product separation (a separation unit downstream is not required) [21]. The novel reactor will be more efficient than the state-of-the-art technology due to an optimal design aimed at circumventing mass and heat transfer resistances. Moreover, the design and optimization of the subcomponents for the balance of plant (BoP) are also addressed. Particular attention is devoted to the optimized thermal integration for improving the overall efficiency of the system at $>90 \%$ and reducing the cost due to low temperature reforming. The traditional reformers include several steps for producing $\mathrm{H}_{2}$ with adequate quality to feed the fuel cell stack $[22,23,24]$.

The new concept addressed in FluidCELL reduces the system complexity thanks to the simultaneous hydrogen conversion and separation in one step (Membrane Reactor, Figure 2) with 
expected thermodynamic advantages (net electric efficiency above 40\%) and reduction of the reforming temperature $\left(\leq 500{ }^{\circ} \mathrm{C}\right)$ while still converting the produced methane to hydrogen. In addition, there is a cost reduction of the other components in the reformer (e.g. heat exchangers) and in the BoP (auxiliary elements) when integrating the membrane reformer to the fuel cell and building up the m-CHP system [7].

The FluidCELL work plan consisted on activities related to the whole product chain: i.e. development of materials/components (catalysts, membranes, supports, sealings,...) through integration/validation at lab-scale, until development/validation of pilot scale ATR-MR and the proof of concept / validation of the new PEM fuel cell m-CHP system. Additionally, assessment of environmental, health \& safety issues -in relation to the new intensified chemical processes and $\mathrm{m}$ CHP was also carried out thanks to a screening life cycle analysis considering all components and steps involved to build the system. For a maximum impact on the European industry, this research was carried out covering the complete value chain of micro-CHP fuel cell systems.

The FluidCELL Project is funded under the FP7 for the Fuel Cell and Hydrogen Joint Undertaking. The Project started the 1st of April 2014 and it will run for 44 months. In the following, the main results in terms of catalysts, membranes and membrane reactors are highlighted.

\section{FluidCELL concept}

Several works have discussed the potentiality of micro-CHP systems based on PEM fuel cells in residential applications $[4,7,8,9]$. The conventional fuel processor lay-out (see Figure 1) consists of steam reformer for converting ethanol into $\mathrm{H}_{2}$ and $\mathrm{CO}$, two water gas shift reactors for converting $\mathrm{CO}$ into $\mathrm{H}_{2}$ and a reactor for reducing the $\mathrm{CO}$ content below $10 \mathrm{ppm}$. The $\mathrm{CO}$ abatement can be carried out either by Preferential Oxidation (PROX) or Methanator (METH).

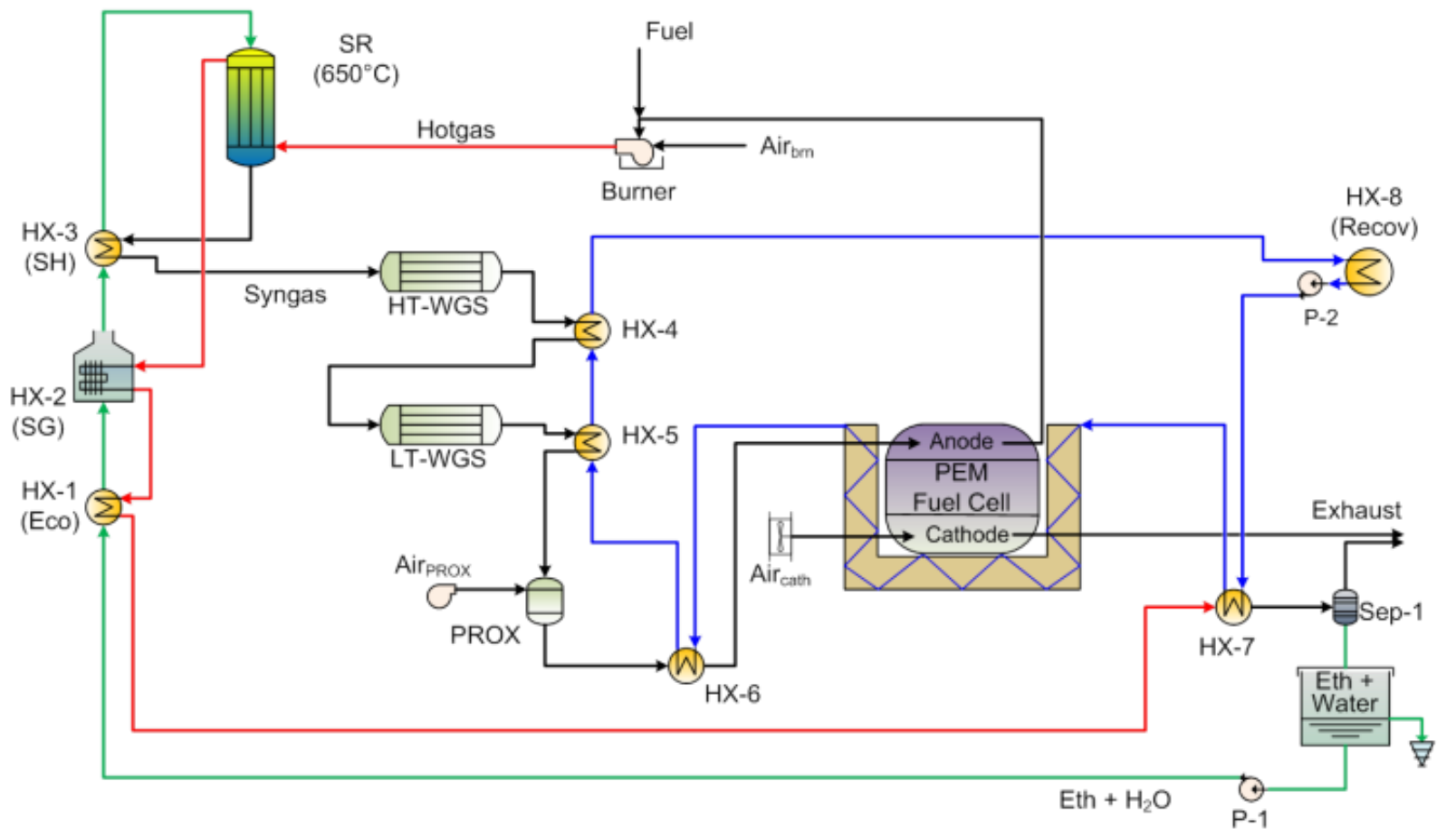

Figure 1. Layout of PEM m-CHP unit using traditional reforming for fuel processing

As discussed in previous works $[25,26,27,28,29,30]$ the resulting net electric efficiency is around $30-35 \%$. The number of reactors and consequent temperature swings introduces losses which penalizes the PEM efficiency which is around 55\%. The FluidCELL concept allows a simplification of the conventional lay-out by replacing the four reactors with one single reactor, namely the Membrane Reactors (see Figure 2). The hydrogen conversion and separation is carried out in this reactor and a pure hydrogen stream is produced which can be directly sent to the PEM fuel cell. 


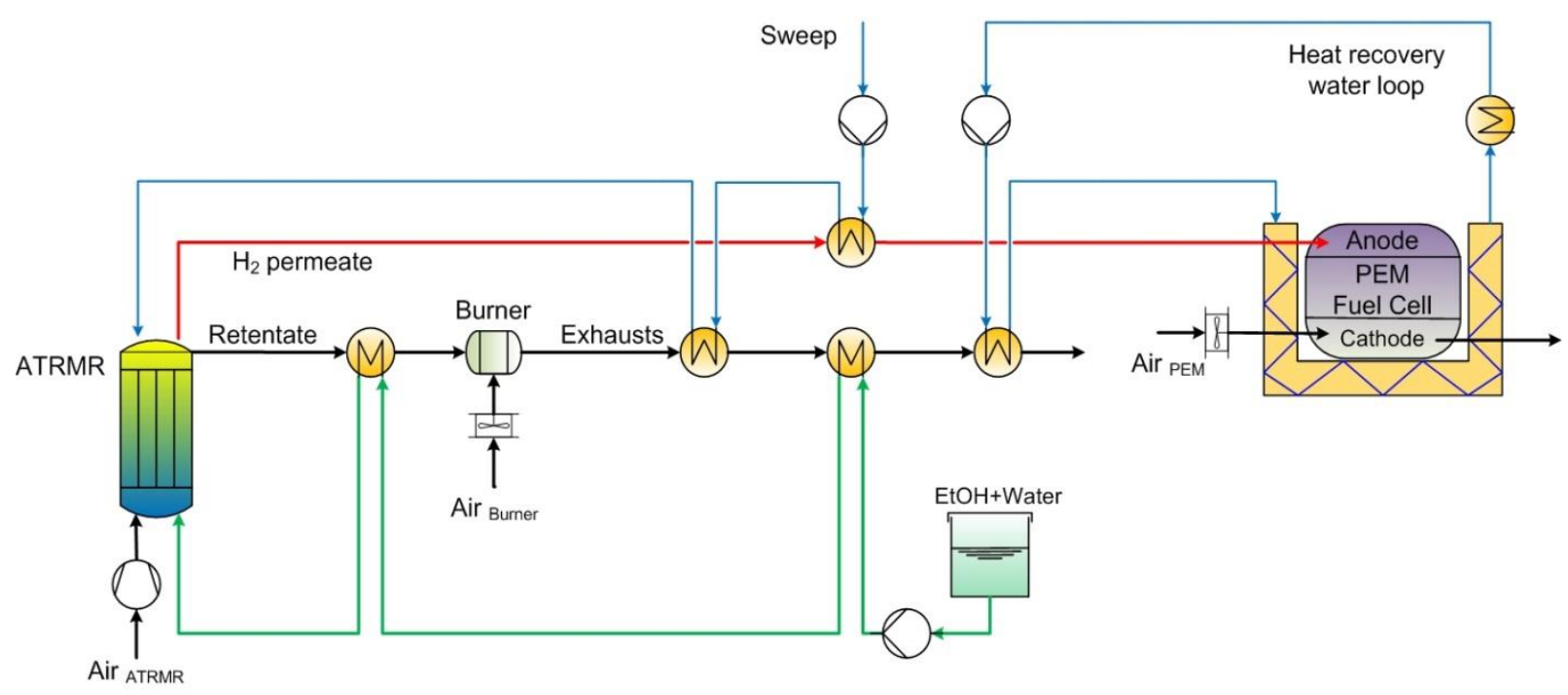

a) Sweep gas layout

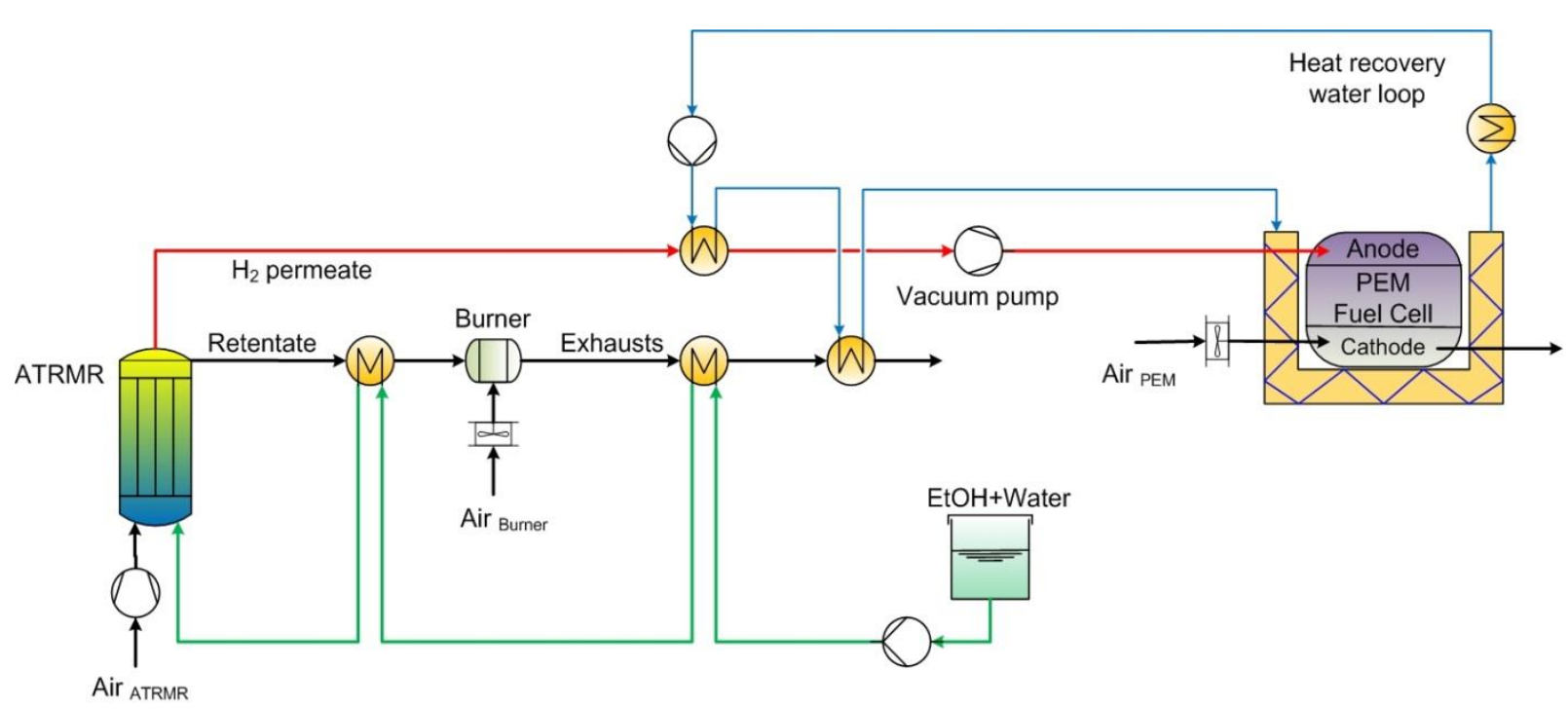

b) vacuum pump layout

Figure 2. Layout of PEM m-CHP unit using membrane reforming for fuel processing: a) sweep gas layout, b) vacuum pump layout

The optimal lay-out for the micro-CHP system, rated $5 \mathrm{~kW}_{\mathrm{el}}$, based on membrane reactor and PEM fuel cells has been defined simulating the performances of two different configurations: sweep gas case and vacuum pump case (see Figure 2). Parametric analysis is performed for both cases evaluating the impact of feed composition (water-to-ethanol ratio) and operative conditions of the membrane reactor (temperature and feed/permeate pressures) on performances and design parameters. Optimal conditions are defined as a trade-off between efficiency and Pd-membranes area. The Pd-membrane area is the parameter which shows the largest variation and significantly affects the reactor size and costs. Therefore, the electric efficiency as a function of membranes surface area for the two considered layouts at various pressures and W/EtOH ratios is summarized in Figure 5. In particular, the electric efficiency of sweep cases has an asymptote, being the pressure extremely influent on membranes extension and only slightly influent on efficiency. The opposite is true for the vacuum pump cases, which show a steep variation: pressure mainly affects the efficiency while the membranes area experiences a small reduction. The effect of W/EtOH ratio is the same in the two cases: $\eta_{\mathrm{el}}-\mathrm{A}_{\mathrm{mem}}$ curves shift down at larger water excess. 


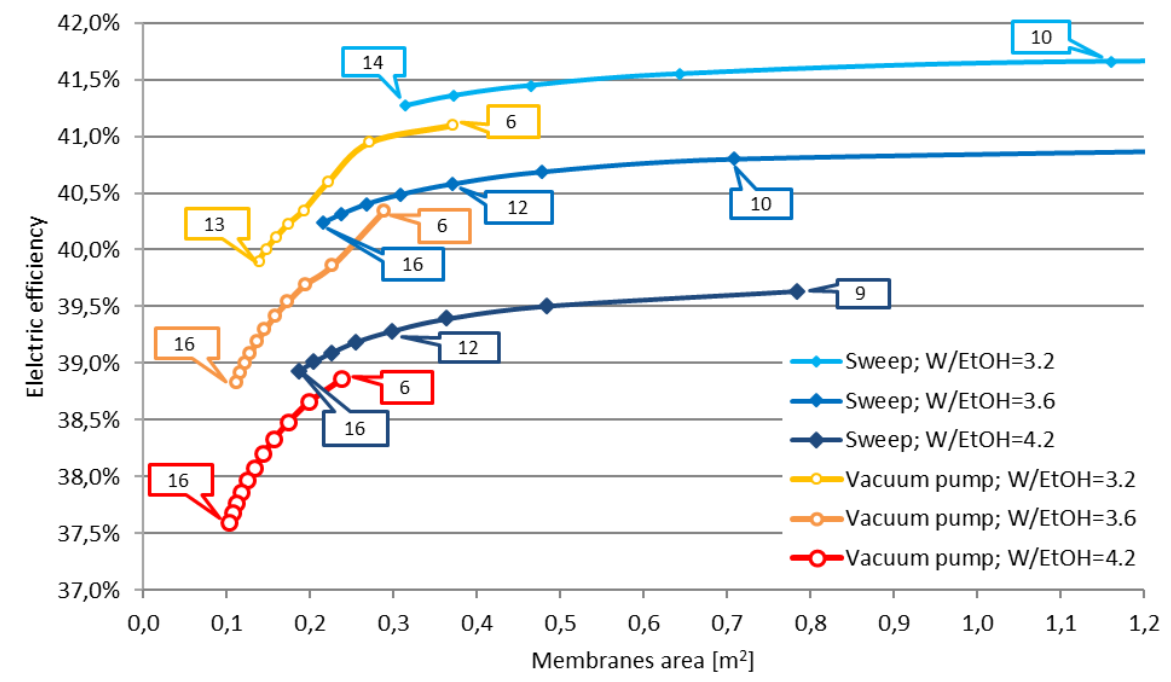

Figure 3. Layouts comparison: electric efficiency and membranes area for different W/EtOH ratios and reactor pressures (full squared $=$ sweep gas layout, Sweep $/ \mathrm{EtOH}=1.6, \mathrm{P}_{\text {permeate }}=1.3 \mathrm{bar}$; empty dots = vacuum pump layout, $P_{\text {permeate }}=0.3$ bar; labels indicate $P_{\text {reactor }}($ bar $)$ ) $[30]$.

Table 1. Simulation results on the performance of the ATR_MR system [30].

\begin{tabular}{|c|c|c|c|c|c|c|c|c|}
\hline \multirow{2}{*}{$\frac{\text { Results }}{\text { W/EtOH }}$} & \multirow{2}{*}{$\begin{array}{c}\text { units } \\
-\end{array}$} & \multirow{2}{*}{$\begin{array}{c}\begin{array}{c}\text { Conventio } \\
\text { nal case }\end{array} \\
6\end{array}$} & \multicolumn{3}{|c|}{ Sweep gas case } & \multicolumn{3}{|c|}{ Vacuum pump case } \\
\hline & & & 3.6 & 4.2 & 3.6 & 3.6 & 3.6 & 3.6 \\
\hline $\mathrm{W} / \mathrm{EtOH}_{\mathrm{adj}}$ & - & - & 4.7 & 5.4 & 4.7 & 4.8 & 4.7 & 4.7 \\
\hline Sweep/EtOH & - & - & 1.6 & 1.6 & 1.6 & - & - & - \\
\hline T reformer & ${ }^{\circ} \mathrm{C}$ & 600 & 500 & 500 & 500 & 500 & 500 & 500 \\
\hline Pressure reaction side & bar & 2 & 12 & 12 & 16 & 6 & 12 & 12 \\
\hline Pressure permeate side & bar & - & 1.3 & 1.3 & 1.3 & 0.3 & 0.3 & 0.4 \\
\hline $\begin{array}{c}\mathrm{O}_{2} / \text { EtOH at inlet of } \\
\text { ATR-MR }\end{array}$ & - & - & 0.43 & 0.42 & 0.42 & 0.46 & 0.44 & 0.44 \\
\hline EtOH consumption & $\mathrm{kg} / \mathrm{h}$ & 1.97 & 1.65 & 1.71 & 1.67 & 1.67 & 1.71 & 1.69 \\
\hline EtOH input [LHV base] & $\mathrm{kW}$ & 12.29 & 12.73 & 12.44 & 12.44 & 12.73 & 12.59 & 12.29 \\
\hline EtOH input [HHV base] & $\mathrm{kW}$ & 13.62 & 14.10 & 13.78 & 13.78 & 14.10 & 13.95 & 13.62 \\
\hline Net AC power output & $\mathrm{kW}$ & 5.00 & 5.00 & 5.00 & 5.00 & 5.00 & 5.00 & 5.00 \\
\hline Gross DC power output & $\mathrm{kW}$ & 5.44 & 5.65 & 5.65 & 5.68 & 5.90 & 5.98 & 5.92 \\
\hline Air compressor power & $\mathrm{kW}$ & - & 0.21 & 0.22 & 0.25 & 0.16 & 0.23 & 0.22 \\
\hline $\begin{array}{c}\text { Cathode air blower } \\
\text { power }\end{array}$ & $\mathrm{kW}$ & 0.13 & 0.13 & 0.13 & 0.13 & 0.13 & 0.13 & 0.13 \\
\hline Vacuum pump power & $\mathrm{kW}$ & - & - & - & - & 0.28 & 0.29 & 0.22 \\
\hline Balance of plant power & $\mathrm{kW}$ & 0.04 & 0.03 & 0.02 & 0.02 & 0.04 & 0.03 & 0.05 \\
\hline Thermal recovery & $\mathrm{kW}$ & 9.08 & 6.54 & 6.89 & 6.61 & 6.52 & 6.83 & 6.75 \\
\hline$\eta_{\mathrm{el}}[\mathrm{LHV}$ base] & $\%_{\mathrm{LHV}}$ & 33.1 & 40.6 & 39.3 & 40.2 & 40.3 & 39.2 & 39.6 \\
\hline$\eta_{\mathrm{el}}[\mathrm{HHV}$ base $]$ & $\%_{\mathrm{HHV}}$ & 29.9 & 36.6 & 35.5 & 36.3 & 36.5 & 35.4 & 35.7 \\
\hline$\eta_{\text {th }}[$ LHV base $]$ & $\%_{\mathrm{LHV}}$ & 63.0 & 53.1 & 54.2 & 53.3 & 52.6 & 53.5 & 53.5 \\
\hline$\eta_{\text {th }}[$ HHV base $]$ & $\%_{\mathrm{HHV}}$ & 57.1 & 47.9 & 48.9 & 48.1 & 47.5 & 48.3 & 48.3 \\
\hline Pd-membranes area & $\mathrm{m}^{2}$ & - & 0.37 & 0.30 & 0.22 & 0.29 & 0.14 & 0.19 \\
\hline PEM stack area (MEA) & $\mathrm{m}^{2}$ & 2.42 & 2.50 & 2.50 & 2.51 & 2.61 & 2.65 & 2.62 \\
\hline$\frac{\mathrm{H}_{2}}{\text { production/permeation }}$ & $\mathrm{Nm}^{3} / \mathrm{h}$ & 4.12 & 3.18 & 3.18 & 3.20 & 3.32 & 3.37 & 3.33 \\
\hline HRF & $\%$ & - & 65.9 & 63.8 & 65.7 & 68.5 & 67.4 & 67.4 \\
\hline $\mathrm{HRF}_{\text {adj }}$ & $\%$ & - & 76.8 & 74.2 & 76.5 & 80.8 & 79.0 & 79.0 \\
\hline
\end{tabular}


For the sweep-gas layout, net electric efficiency higher than $40 \%$ can be achieved for a wide range of operative conditions, but large Pd-membranes area is required $\left(\approx 0.4 \mathrm{~m}^{2}\right)$; for the vacuum pump layout efficiency is lower (down to $39 \%$ ), but Pd-membranes area is lower too $\left(\approx 0.2 \mathrm{~m}^{2}\right)$. Future work is the economic evaluation of the system for off-grid installations. Main results of the simulations for the two investigated layouts of ATR-MR, together with the conventional case based on conventional fuel processor (SR) are summarized in Table 1 [30] In general the FluidCELL concept increase the net electric efficiency by about $20 \%$ with respect to conventional fuel processor. The fuel cell active area is slightly larger than the conventional case to balance the higher auxiliaries consumptions. Finally, the overall efficiency of the FluidCELL and conventional case is similar, meaning that, in the conventional case, the thermal efficiency balances the lower electric efficiency.Error! Reference source not found.

Detailed information on the simulation can be found in Foresti et al. [30].The sweep gas layout has been selected for the final prototype. In case of damage of the membranes in the membrane reactor, with consequence impurities in the permeated hydrogen, methanator will be included as guard bed between the reformer and the PEM fuel cell. This is just adopted for the prototype since the system is still under development.

\section{Material and methods}

\subsection{Catalyst}

Catalysts play a crucial role in terms of complete ethanol conversion and maximizing the hydrogen yield. The literature surveys reveal that the ethanol conversion and selectivity to hydrogen during reforming reaction highly depend on the type of metal used, type of precursors, preparation methods, type of catalyst support, presence of additives, and operating conditions, i.e. water/ethanol molar ratio and temperature. The ethanol reforming over several metals (supported on different materials) has been extensively reported in recent literature. Various noble metals ( $\mathrm{Pt}, \mathrm{Pd}, \mathrm{Rh}, \mathrm{Ir}$, $\mathrm{Ru})[31,32,33]$ are well-known for their high catalytic activity, but $\mathrm{Pt}$ and $\mathrm{Rh}$ appear particularly appropriate at lower temperatures. Among non-noble metals, nickel [34] is one of the most studied metals, because of its high activity and its relatively low cost; cobalt has also been investigated due to its aptitude to $\mathrm{C}-\mathrm{C}$ bonds rupture. However, several studies reported the promising performances of bimetallic systems, which exploit the synergistic effect related to the presence of two active species [35,36,37,38,39], showing significantly different catalytic properties than either of the parent metals. In addition, supports strongly affect the catalyst activity and stability. Different supports have been proposed in literature and the most suitable performance was shown by metal oxides with redox properties [40]. Of particular interest are the $\mathrm{CeO}_{2}$ and $\mathrm{CeO}_{2}-\mathrm{ZrO}_{2}$ based supports, as these are known to greatly improve catalytic performance due to support metal interaction and oxygen storage capabilities [41,42]. This capability has been attributed to some unique properties of $\mathrm{CeO}_{2}$, such as the high oxygen storage capacity, the high oxygen mobility and the ability of cerium to switch easily between the oxidized and reduced states $\left(\mathrm{Ce}^{3+} \leftrightarrow \mathrm{Ce}^{4+}\right)$.

Two different series of catalysts were prepared by wet impregnation according to procedures previously reported: $\mathrm{Pt}-\mathrm{Ni} / \mathrm{CeO}_{2}[38,39] \mathrm{Pt}-\mathrm{Ni} / \mathrm{CeO}_{2} / \mathrm{SiO}_{2}$ [43]. Pt-Ni/ $/ \mathrm{CeO}_{2} / \mathrm{SiO}_{2}$ catalysts with different $\mathrm{CeO}_{2} / \mathrm{SiO}_{2}$ ratios $(25,30$ and $40 \mathrm{wt} \%)$ were developed. The prepared supports were denoted as $\mathrm{XCe}(\mathrm{X}=25,30,40)$ where $\mathrm{X}$ represented the $\mathrm{CeO}_{2}$ content (wt\%), likewise, the catalysts were indicated with the symbols PtNiXCe.

Chemical composition of the samples was measured by X-ray fluorescence (XRF) spectrometry. Textural properties were analyzed by $\mathrm{N}_{2}$ adsorptionedesorption experiments at liquid nitrogen temperature. Average crystalline sizes were measured by X-ray diffraction (XRD) through Scherrer formula. Temperature Programmed Reduction (TPR) and Oxidation (TPO) on fresh and spent catalysts, respectively, were performed in situ, in the laboratory apparatus. Thermogravimetric analysis on the samples after stability tests were also performed. The different characterisation 
equipment and procedures are detailed elsewhere [43]. In addition, fluidization tests were also carried out to assess the mechanical stability.

The experiments of oxidative steam reforming of ethanol were conducted in a fixed-bed continuous flow stainless steel reactor. The test setup used in the experiments has been described in more detailed previously [43].

The catalysts prepared at different $\mathrm{CeO}_{2} / \mathrm{SiO}_{2}$ ratio were tested between 300 and $600{ }^{\circ} \mathrm{C}$ while the stability was evaluated at $500{ }^{\circ} \mathrm{C}$. The feed ratio was preliminary fixed to 4 and the $\mathrm{H}_{2} \mathrm{O} / \mathrm{C}_{2} \mathrm{H}_{5} \mathrm{OH}$ mixture was introduced at an ethanol flow rate of $0.13 \mathrm{~mL} / \mathrm{min}$. The air flowrate was fixed to 119 $\mathrm{Ncm}^{3} / \mathrm{min}$ and the diluting stream was modulated in order to obtain the following composition: $10 \% \mathrm{C}_{2} \mathrm{H}_{5} \mathrm{OH}: 5 \% \mathrm{O}_{2}: 40 \% \mathrm{H}_{2} \mathrm{O}: 45 \% \mathrm{~N}_{2}$ (water/ethanol mol ratio r.a. $=4$ and oxygen/ethanol mol ratio r.o. $=0.5$ ); gas hourly space velocity was fixed to $5600 \mathrm{~h}^{-1}$.

Ethanol conversion (X) and hydrogen yields (Y) were evaluated following the Eq. (1) and Eq. (2), respectively, while the formula for carbon formation rate (CFR) is reported in Eq. (3).

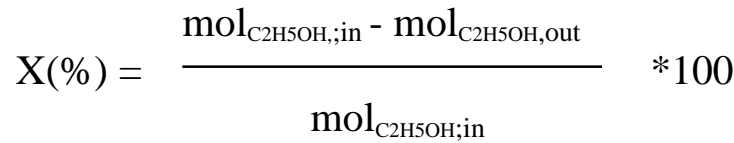

$$
\begin{aligned}
& \mathrm{Y}(\%)=\frac{\mathrm{mol}_{\mathrm{H} 2}}{6 *\left(\mathrm{~mol}_{\mathrm{C} 2 \mathrm{H} 5 \mathrm{OH}, \mathrm{in})}\right.} * 100 \\
& \mathrm{CFR}=\frac{\text { mass }_{\text {coke }}}{\text { mass }_{\text {catalyst }} * \text { mass }_{\text {carbon,fed }} * \text { time }} * 100
\end{aligned}
$$

\subsection{Membranes preparation, characterisation and permeation tests}

Much effort has been put in the development of Pd-based membranes for selective $\mathrm{H}_{2}$ separation in the literature in order to overcome the barrier towards large-scale industrial applications $[11,12]$. In general, membrane stability over a long period of time with sufficient perm-selectivity is the key parameter which would make these membranes interesting for industrial scale. The selection of the proper support where Pd-layers are deposited becomes important in order to achieve this interesting goal. Surface roughness and the presence of large pores inhibit the deposition of thin palladium membrane. Asymmetric porous ceramic tubes have good surface quality to support very thin $(<5$ $\mu \mathrm{m}) \mathrm{Pd}$-based membranes. Ceramic supports also show improved $\mathrm{H}_{2}$ diffusion through the support, thus enhancing permeations through the membranes [44]. However, the mechanical strength of these supports is much lower compared to porous metallic supports. Therefore, thicker ceramic supports are needed. On the other side, metallic supported membranes have shown very good stabilities over time with outstanding selectivities [45,46]. However, the permeance values measured are 3-4 times lower than ceramic supported membranes when membranes are developed by direct electroless plating (ELP) deposition [44,45], thus higher membranes area should be installed in the reactor in order to achieve the desired targets of $\mathrm{H}_{2}$ permeation with a corresponding economical penalty for the process. As it can be concluded, there is not yet an ideal membrane for $\mathrm{H}_{2}$ separation and still a compromise between durability and functionality should be achieved. Both metallic and ceramic supported Pd-membranes have been used in the literature in fixed bed and fluidized bed configurations showing high resistances to erosion. 
The systhesis of Pd-Ag membranes was carried by different techniques using previously reported procedures: direct simultaneous Pd and Ag electroless plating (ELP) $[44,45,46,47]$, direct physical vapour deposition magnetron sputerring (PVD-MS) [48,49] or combining PVD-MS and ELP techniques [48]. Pd-Ag membranes were supported on ceramic porous tubes (10/7 mm o.d./i.d. (provided by Rauschert Kloster Veilsdorf) and prepared by ELP with various thicknesses by varying the plating time $(15,30,45,50,60$ and 70 minutes) for ultra-thin film [50] and between 4 to $5 \mathrm{~h}$ for thin film $(\sim 4 \mu \mathrm{m})$. The plating bath when preparing the ultra-thin membranes was composed of palladium acetate $(10 \mathrm{mM})$, silver nitrate $(0.4 \mathrm{mM})$, EDTA $(0.15 \mathrm{M})$, ammonia $(5 \mathrm{M})$ and hydrazine $(15 \mathrm{mM})$ [50]. On the other side, the plating bath when preparing the thin membranes was composed of palladium acetate $(11.70 \mathrm{mM})$, silver nitrate $(0.64 \mathrm{mM})$, EDTA $(0.15 \mathrm{M})$, ammonia (5 M) and hydrazine (15 mM).

The Pd and Ag contents of the Pd-Ag membrane layer were determined by the difference of their initial and final concentrations in the plating solution measured using a Varian Vista MPX inductively coupled plasma optical emission spectrometer (ICP-OES). The thickness was analyzed by an Environmental Scanning Electron Microscope (ESEM) (FEI Quanta 250 FEG) and for each membrane at least 5 measurements were carried out. In addition, the EDX coupled to the ESEM was used to analyze the composition of the selective layer. The XRD patterns of the Pd-based films were examined with an X-ray Bruker D8 Advance diffractometer, the scan speed was $1.00^{\circ} \min ^{-1}$ and the step width $0.02^{\circ}$, in the range $2 \Theta=30-90^{\circ}$ with a $\mathrm{K} \beta$ radiation at $40 \mathrm{kV}$ and $15 \mathrm{~mA} . \mathrm{H}_{2}$ and $\mathrm{N}_{2}$ permeation tests have been carried out in the permeation setup at the TUE described by Medrano et al. [46].

\subsection{Lab scale reactors}

Once the catalysts and membranes were developed showing promising results, both were combined in modules for lab scale testing under reacting conditions. The fluidized bed membrane reactor set up was designed and built for hosting Pd-based membranes produced in the FluidCELL project as well as commercial ones.

The experimental tests have been carried out at the TU/e using the permeation setup under reactive conditions (Figure 4). This experimental set-up is able to perform reactive permeation experiments with a maximum of five membranes. There are three thermocouples, and two pressure sensors distributed over the reactor height. A vacuum pump can be switched on to decrease the partial pressure of the permeate side, as low as $10 \mathrm{mbar}$. The system does further include feed connections to pure components as $\mathrm{O}_{2}, \mathrm{H}_{2}, \mathrm{~N}_{2}, \mathrm{CO}, \mathrm{CO}_{2}, \mathrm{CH}_{4}$ and pressurized air. The components can be fed through a mass flow controller, which depending on the type of mass flow controller can have a maximum flow of $2 \mathrm{~L} / \mathrm{min}(\mathrm{CO})$ up to $22 \mathrm{~L} / \mathrm{min}\left(\mathrm{N}_{2}\right)$. There are two separate storage vessels for ethanol and water, which can be fed to a CEM where both components can be evaporated. All the tubes connected to the reactor inlet are traced, as well as the tubes used for the retentate, to maintain the temperature well above the boiling point of water and ethanol. The retentate can then be analyzed by FT-IR. The FT-IR is able to measure concentrations (after calibration) for water and ethanol, which was not possible at a lab scale. The retentate then passes through a cooler where the water and ethanol are condensed and separated in a flash column. The retentate is connected to a Sick $®$ analyzer, which is able to measure concentrations of the dry retentate. A similar analyzer is also connected to the retentate side, which is able to measure hydrogen concentrations in the range of $0-100 \%$ and COx concentrations on a ppm accuracy. The permeate side can be connected to a Horiba film flow meter at which flow rates can be measured accurately, depending on the one used in the range of $0.2-10 \mathrm{ml} / \mathrm{min}, 0.02-1 \mathrm{l} / \mathrm{min}$, and $0.2-10 \mathrm{l} / \mathrm{min}$. The membranes can also be assessed individually, by closing valves manually which are placed on top of the reactor. 

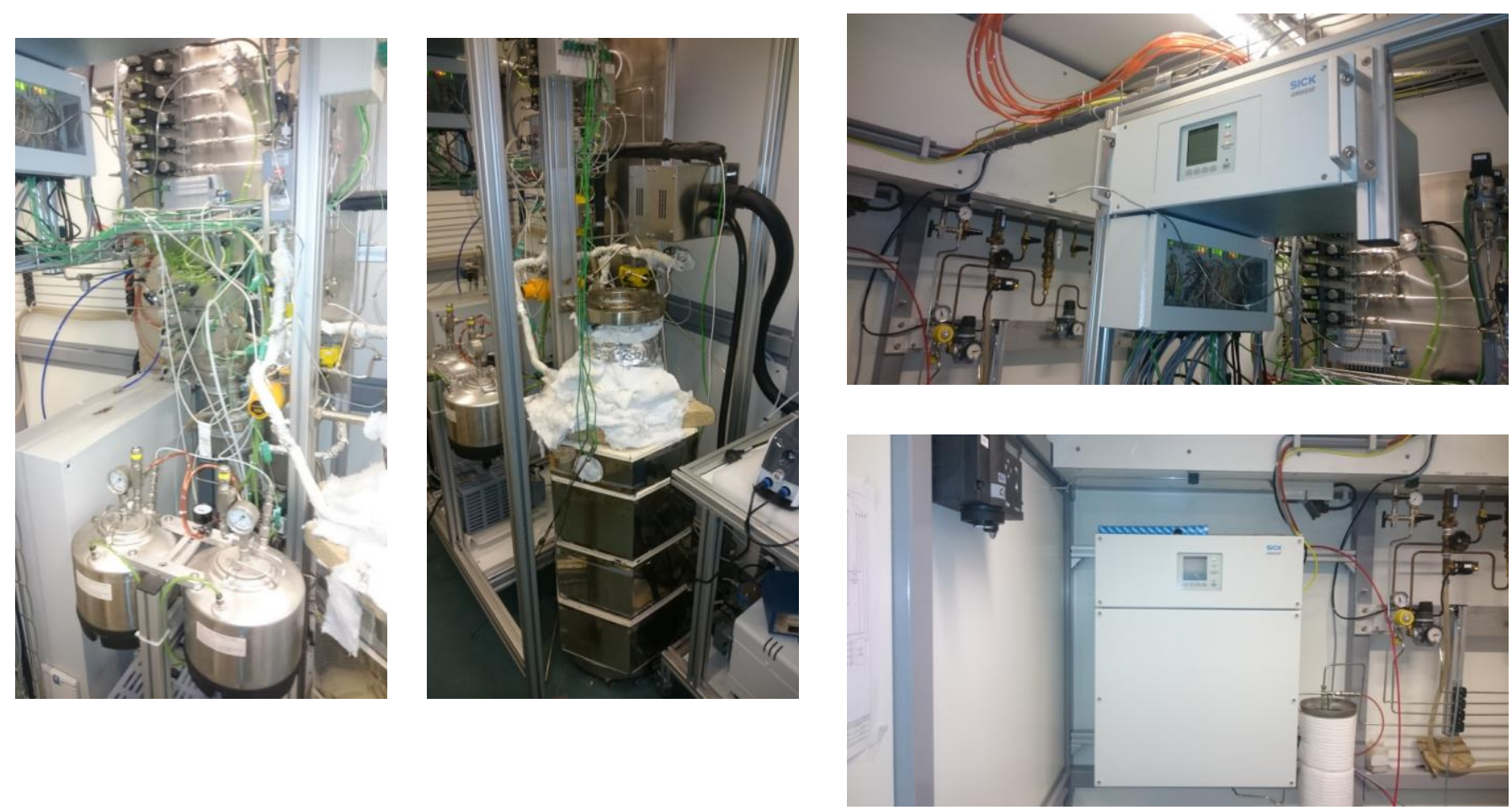

Figure 4. The lab facility at the TU/e

\section{Results and Discussion}

\subsection{Catalyst}

\subsubsection{Structural characterization of the catalyst and support}

The chemical composition obtained by XRF analysis as well as the specific values of the support and bimetallic catalysts surface area are presented in Table 2 [43]. The experimental $\mathrm{CeO}_{2}$ and metal contents were close to the nominal values, indicating the effectiveness of the preparation procedure. BET measurements show that all the catalysts exhibited high surface areas. Only a slight decrease of surface area with $\mathrm{CeO}_{2}$ loadings was observed over the supports, ascribable to the partial plugging of $\mathrm{SiO}_{2}$ pores, which hindered $\mathrm{N}_{2}$ adsorption [51]. However, the 30 and 40Ce samples displayed practically the same surface area. The deposition of $\mathrm{Pt}$ and Ni resulted in a small decrease of specific surface area with respect to that observed for the $\mathrm{CeO}_{2} / \mathrm{SiO}_{2}$ supports: the lowest SSA value was recorded over the PtNi40Ce catalyst, despite, also for the final catalysts, no relevant differences were observed for the catalyst having 30 and $40 \mathrm{wt} \%$ of ceria loading. This further area decrease may be a consequence of the support pores blocking by the nickel oxide or metallic platinum phase. Further details on catalyst microstructure as well as on $\mathrm{H}_{2}$-TPR tests are detailed in Palma et al. [43].

Table 2. Physicochemical properties of the supports and the bimetallic catalysts [43].

\begin{tabular}{lccccccc}
\hline Sample & $\begin{array}{c}\mathrm{SiO}_{2} \\
(\mathrm{wt} \%)\end{array}$ & $\begin{array}{c}\mathrm{CeO}_{2} \\
(\mathrm{wt} \%)\end{array}$ & $\begin{array}{c}\mathrm{Ni} \\
(\mathrm{wt} \%)\end{array}$ & $\begin{array}{c}\mathrm{Pt} \\
(\mathrm{wt} \%)\end{array}$ & $\begin{array}{c}\mathrm{SSA} \\
\left(\mathrm{m}^{2} / \mathrm{g}\right)\end{array}$ & $\begin{array}{c}\mathrm{d}_{\mathrm{CeO} 2} \\
(\AA)\end{array}$ & $\begin{array}{c}\mathrm{d}_{\mathrm{NiO}} \\
(\AA)\end{array}$ \\
\hline $\mathrm{SiO}_{2}$ & 100 & - & - & - & 400 & - & - \\
$25 \mathrm{Ce}$ & 75.2 & 24.8 & - & - & 294 & 64 & - \\
$30 \mathrm{Ce}$ & 68.3 & 31.7 & - & - & 240 & 78 & - \\
$40 \mathrm{Ce}$ & 58.1 & 41.9 & - & - & 242 & 78 & - \\
$\mathrm{PtNi} 25 \mathrm{Ce}$ & 72.3 & 23.8 & 2.93 & 0.97 & 239 & 62 & 135 \\
$\mathrm{PtNi} 30 \mathrm{Ce}$ & 65 & 30.2 & 3.73 & 1.09 & 225 & 82 & 85 \\
$\mathrm{PtNi} 40 \mathrm{Ce}$ & 54.6 & 39.4 & 4.80 & 1.25 & 219 & 73 & 127 \\
\hline
\end{tabular}


The supports and bimetallic catalyst was tested under fluidization condition at both low and high temperatures. The particle size distribution after fluidization tests has been compared with the one of the catalyst as received. The results are shown in Figure 5, as particle size distribution (measured by laser diffraction in wet condition with Fritsch Analysette 22) of fresh supports and after fluidization at 25 and $400{ }^{\circ} \mathrm{C}$ for $24 \mathrm{~h}$. Ceria and ceria/zirconia based supports showed very weak mechanical resistance. Particle size distribution were not stable under fluidization being this effect stronger when testing at $400{ }^{\circ} \mathrm{C}$ (see Figure 5-a and -b). On the other side, the $\mathrm{CeO}_{2} / \mathrm{SiO}_{2}$ support (Figure 5-c) and the $\mathrm{Pt}-\mathrm{Ni} / \mathrm{CeO}_{2} / \mathrm{SiO}_{2}$ catalyst (Figure 5-d) showed a good resistance to attrition and size distribution stability under fluidization. Particle size distributions were stable under fluidization in both cold and hot fluidization tests. Therefore silica gel was chosen as mechanical support in order to maintain the fluidization regime in the reactor. In addition, this material is characterized by a very high specific surface, which is expected to enhance active species dispersion and, as a consequence, the specific activity of the final catalyst.

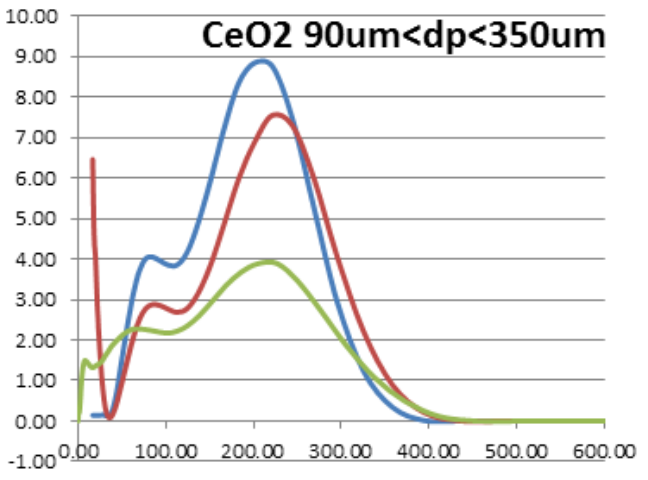

a)

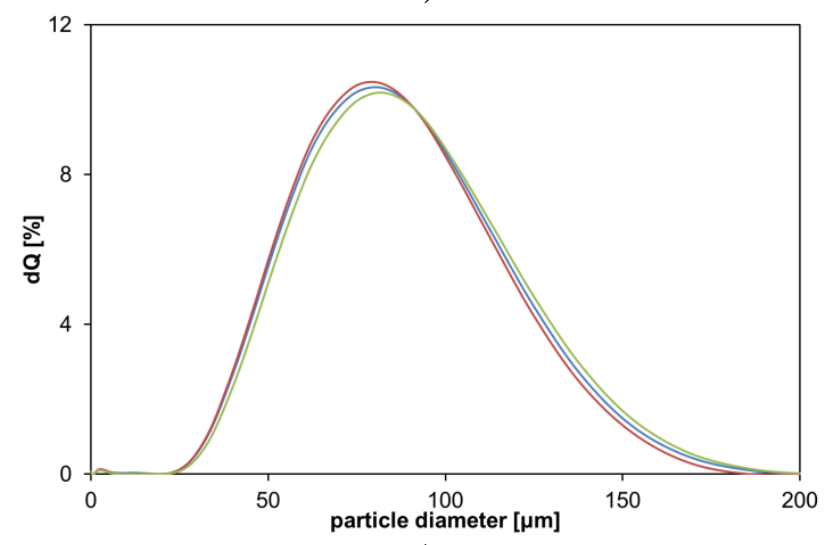

c)

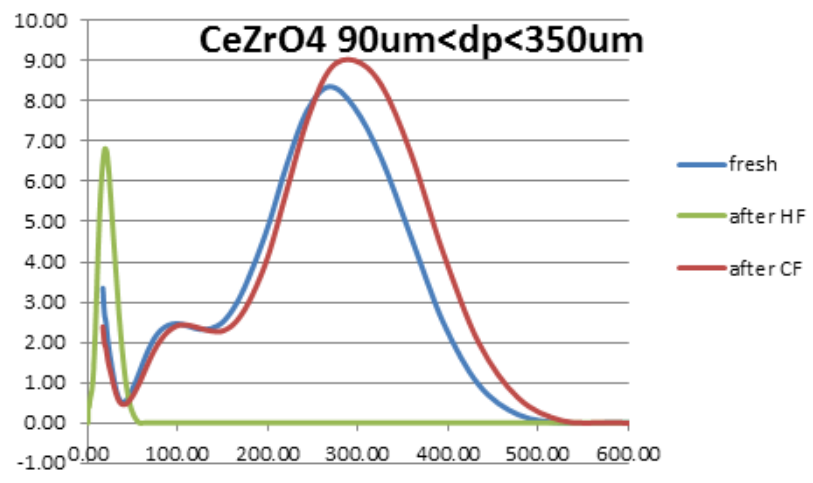

b)

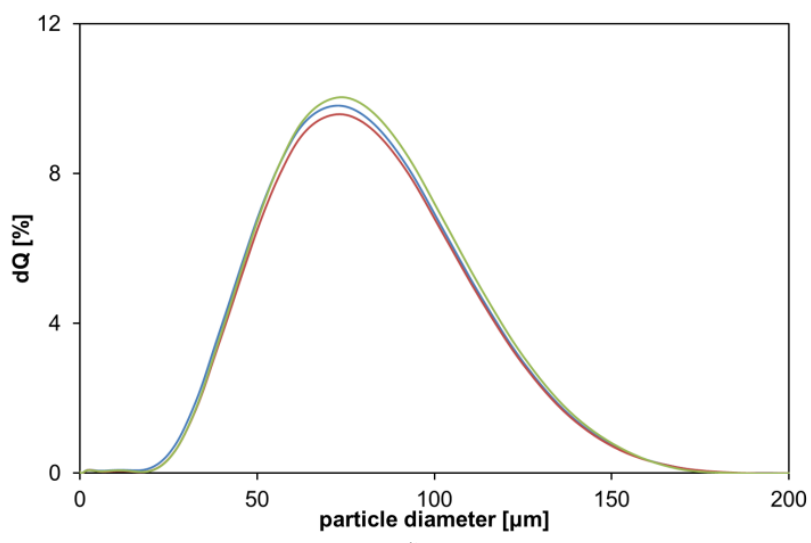

d)

Figure 5. Particle size distribution before and after fluidization test (blue: fresh, red: after Room Temp. fluidization, green: after hot fluidization, $400{ }^{\circ} \mathrm{C}$ ). a) $\mathrm{CeO}_{2}$ support; b) $\mathrm{CeO}_{2} / \mathrm{ZrO}_{2}$ support; c) $\mathrm{CeO}_{2} / \mathrm{SiO}_{2}$ supports; d) $\mathrm{Pt}-\mathrm{Ni} / \mathrm{CeO}_{2} / \mathrm{SiO}_{2}$ catalyst.

\subsubsection{Catalytic activity and stability}

The catalytic activity of the PtNiXce samples tested under oxidative/autothermal (ATR) and nonoxidative (ESR) conditions was evaluated between 300 and $600{ }^{\circ} \mathrm{C}$. The ethanol conversions under oxidative and non-oxidative conditions as a function of the temperature for different space velocity (GHSV) are detailed in Figure 6. Total ethanol conversion was recorded at T $>430{ }^{\circ} \mathrm{C}$ for ESR as well as oxidative/autothermal tests and the results were not affected by GHSV variations. However, in the ESR case, the reduction of contact time was responsible for lessened conversions of $\mathrm{C}_{2} \mathrm{H}_{5} \mathrm{OH}$, which at $340{ }^{\circ} \mathrm{C}$ dropped to $73 \%$ and $47 \%$, respectively at $20000 \mathrm{~h}^{-1}$ and $30000 \mathrm{~h}^{-1}$ (Figure 6-a). On the contrary, a conversion of almost $100 \%$ was observed at $10000 \mathrm{~h}^{-1}$ even at $\mathrm{T}<340{ }^{\circ} \mathrm{C}$ during 
oxidative steam reforming reaction (Figure 6-b). It is also interesting to note that oxygen (not shown) was completely converted between 300 and $600{ }^{\circ} \mathrm{C}$ and this parameter was not affected by contact time decrease from 360 and $120 \mathrm{~ms}$. When $\mathrm{O}_{2}$ was added to the reaction mixture, the ethanol conversion was higher in comparison with the values obtained in SR reaction for $\mathrm{T}<$ $430{ }^{\circ} \mathrm{C}$. Other authors [52] reported that in the presence of rare earth metals oxides, the increase of ethanol conversion may be attributed to the higher $\mathrm{C}-\mathrm{C}$ bond cleavage capacity promoted by oxygen, which may result in ethanol dehydrogenation to acetaldehyde, oxidation of ethoxy species to acetate and their decomposition to $\mathrm{CO}_{2}$. In particular, it was observed that, in the presence of oxygen, the reaction rates for oxidation reactions are higher than those under ESR conditions. Moreover, whatever the contact time selected, the system, under both oxidative and non-oxidative conditions, reached thermodynamic equilibrium at almost $480{ }^{\circ} \mathrm{C}$.

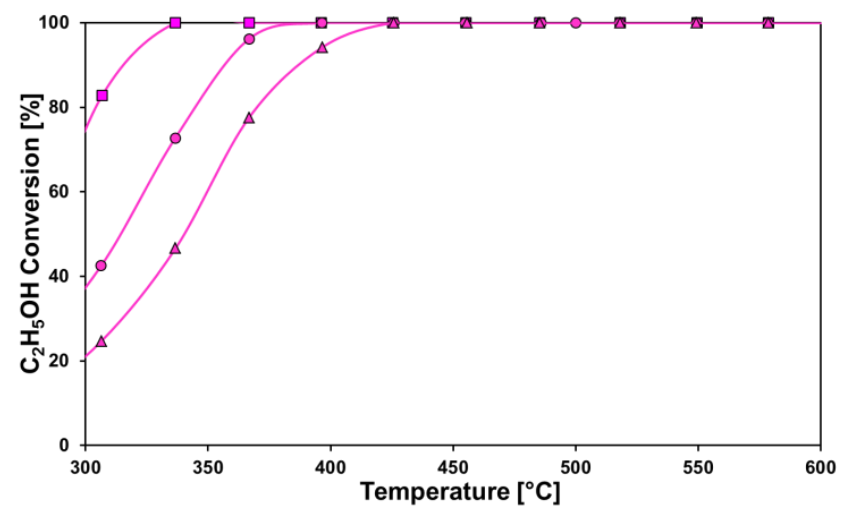

a)

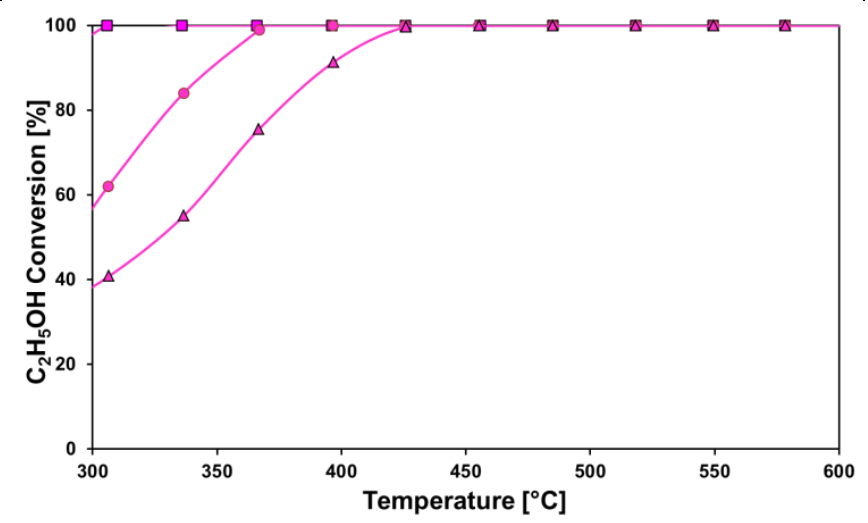

b)

Figure 6. $\mathrm{C}_{2} \mathrm{H}_{5} \mathrm{OH}$ conversion as a function of temperature for GHSV=10000 $h^{-1}(\square), 20000 \mathrm{~h}^{-1}(\bullet)$ and $30000 h^{-1}(\Delta)$ : a) ethanol steam reforming (ESR) and b) oxidative steam reforming.

Stability performances over the three catalysts in terms of ethanol conversion under oxidative conditions are shown in Figure 7. All the bimetallic catalysts exhibited excellent stability: during $100 \mathrm{~h}$ reaction, the samples maintained a stable catalytic activity without deactivation. Lower durability was observed with PtNi25Ce while PtNi40Ce showed the strongest deactivation. The best stability performances were observed with the PtNi30Ce catalyst.

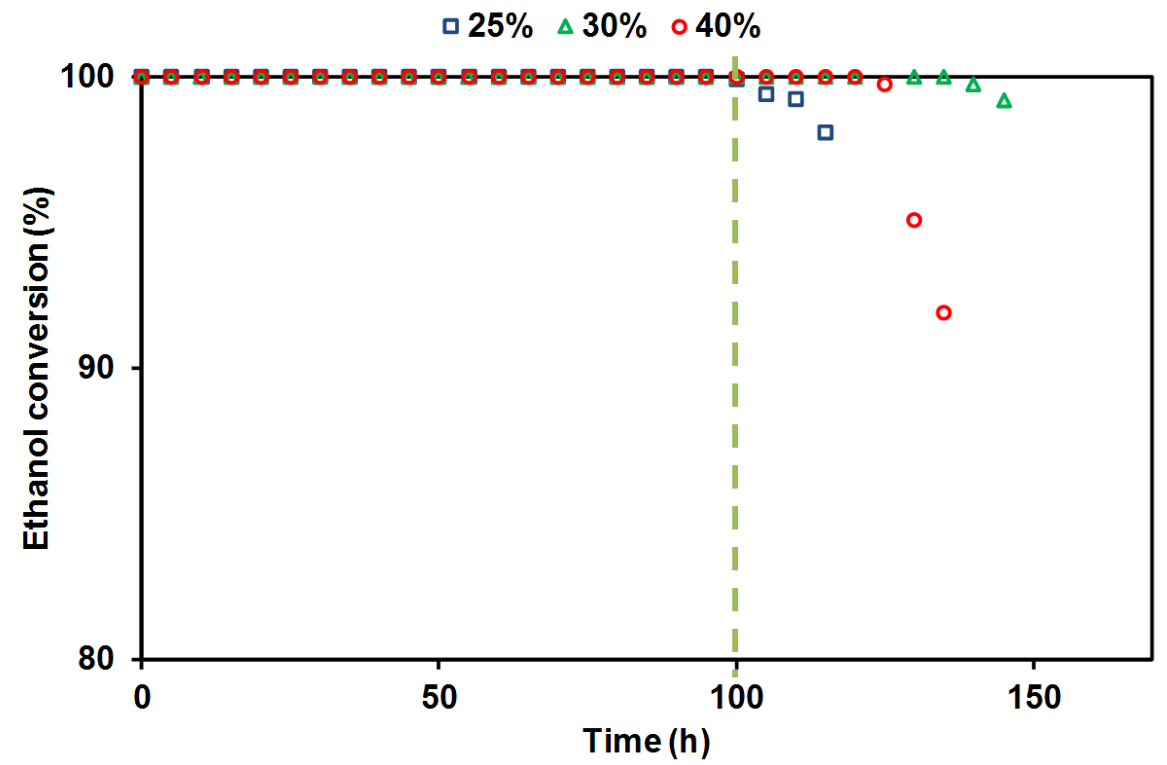

Figure 7. Stability performance over the three catalysis in terms of ethanol conversion; PtNi25Ce (square), PtNi30Ce (triangle), PtNi40Ce (circle), equilibrium (dashed vertical line); $\mathrm{T}=500{ }^{\circ} \mathrm{C}, \mathrm{GHSV}=$ $5600 \mathrm{~h}^{-1}$, r.a. $=4$, r.o. $=0.5$. $[43]$. 
The spent catalysts were characterised by thermogravimetric, TPO and XRD analysis to investigate the factors resulting in their different stability performance. Carbon formation rate as a function of of $\mathrm{Ni}$ average crystalline sizes for the different catalyst is shown in Figure 8. PtNi30Ce catalyst showed the lowest carbon selectivity. Also other authors [53,54,55] observed that coke deposition is strongly dependent from the nickel crystallites, proving that the largest Ni crystallites caused the greater carbon deposition. At comparable operative conditions in terms of temperature, space velocity and water/ethanol ratio the catalysts developed in the present study assured CFR values three order of magnitude lower than that found in other works. Detailed information on the catalyst activity and stability can be found in Palma et al. [43].

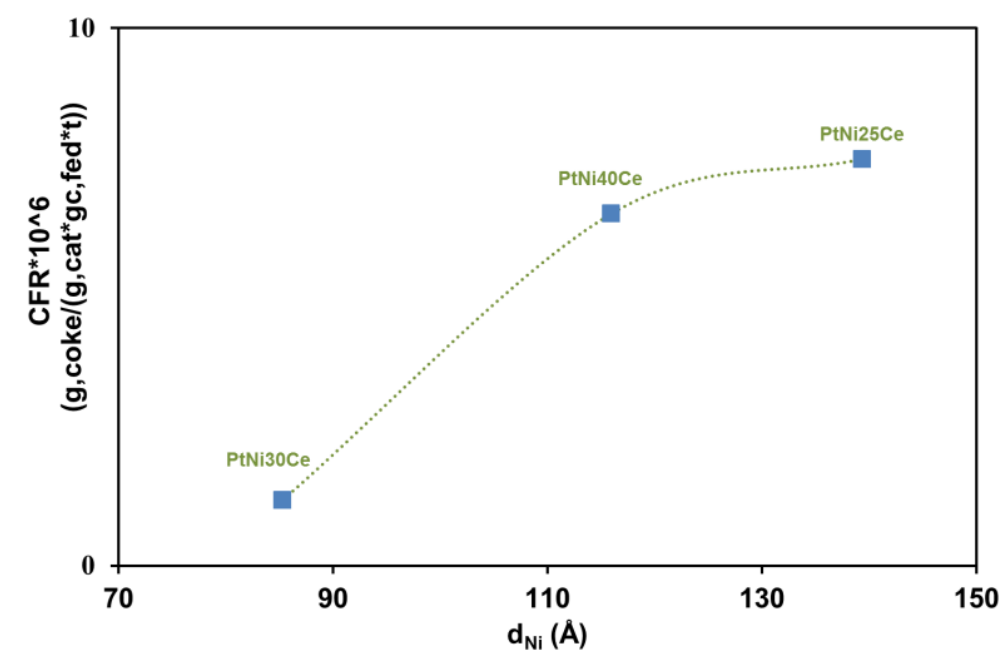

Figure 8. Carbon formation rate as a function of of $\mathrm{Ni}$ average crystalline sizes for the different catalyst [43].

\subsubsection{Kinetic test and model}

Kinetic tests have been carried out in the kinetic setup described in Ruocco et al. [56] to determine which kinetic model better describes the reaction of ethanol autothermal reforming. The operating conditions in terms of $\mathrm{S} / \mathrm{C}$ and $\mathrm{O} / \mathrm{C}$ have been selected considering the simulation for defining the optimal lay-out and performances of a rated $5 \mathrm{~kW}_{\text {el }}$ PEM fuel cell $\mathrm{m}$-CHP system [30] in which the overall thermal balance of the plant has been assessed and compared with conventional ethanol reforming including also the presence of the PEM fuel cell. The S/C ratio used would circumvent the carbon formation on the catalyst, although independent study on a similar catalyst (see Ref. [57]) show that at low $S / C$ ratios coke selectivities of this catalyst were among the lowest found in the recent literature.

The results of these tests (and additional tests with oxygen addition, not reported here) suggested us to describe the autothermal reforming of ethanol with the following set of reactions as illustrated in Figure 9. Two different pathways have been considered for the ethanol autothermal reforming. In the first pathway, the ethanol first reacts with $\mathrm{O}_{2}$, the remaining ethanol is converted into equivalent ethanol $\left(\mathrm{C}_{2} \mathrm{H}_{5} \mathrm{OH}_{\mathrm{eq}}\right)$ and after that followed by SMR and WGS. In the second pathway the ethanol is instantaneously converted into a mixture of gas corresponding to equivalent ethanol, $\left(\mathrm{C}_{2} \mathrm{H}_{5} \mathrm{OHeq}=\right.$ $\mathrm{CH}_{4}+\mathrm{H}_{2}+\mathrm{CO}$ ) and after that the methane partial oxidation occurs followed by the SMR and WGS. 


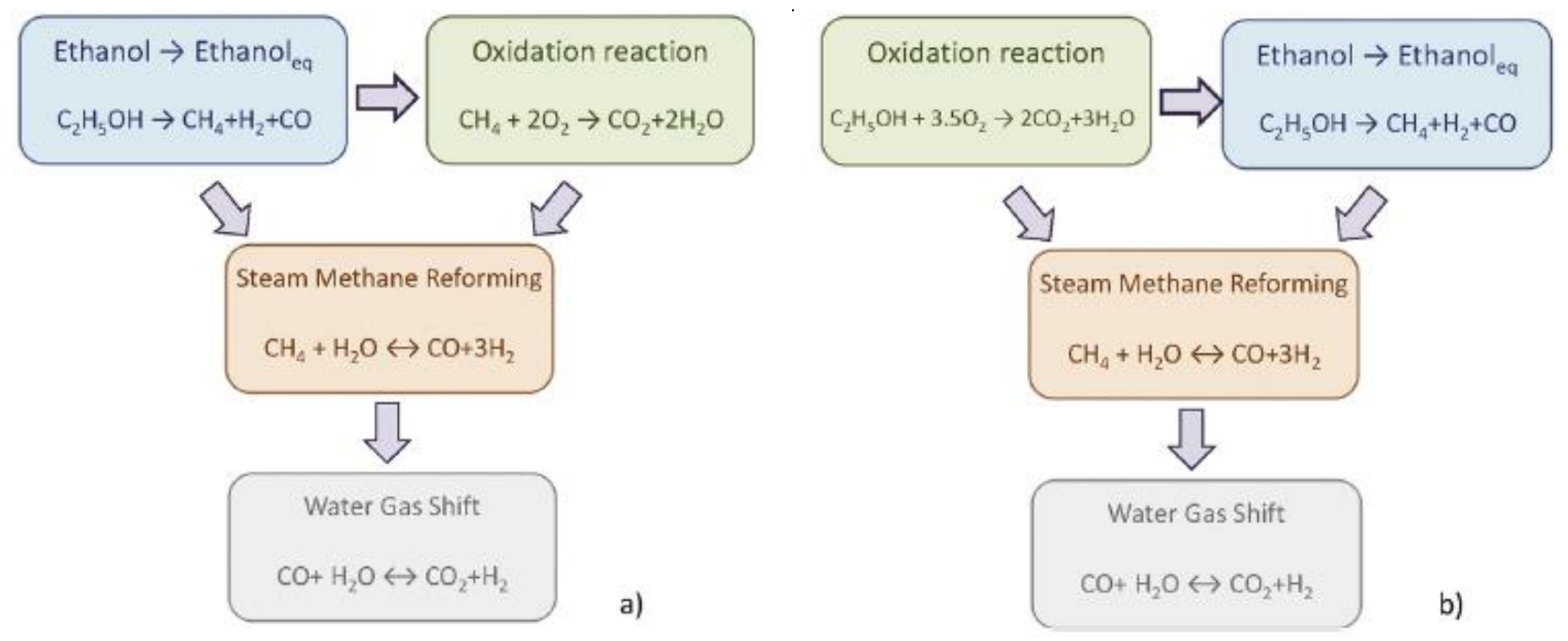

Figure 9. Set of possible reactions for ethanol autothermal reforming [56].

The set of equations and the variables used for the kinetic model and the methodology for calculating the rate of conversion for each reaction case ( $a$ and b) as well as the comparison between the experimental results and model for ethanol steam reforming and ethanol autothermal reforming reactions at different operating conditions are reported in Ruocco et al [56]. From the results the ethanol autothermal reforming can be assumed to follow the pathway described in Figure 9-b. A comparison between the two experiments and the model predictions are plotted in Figure 10. The results show that the modelling is predicting the outlet composition with a very low error.
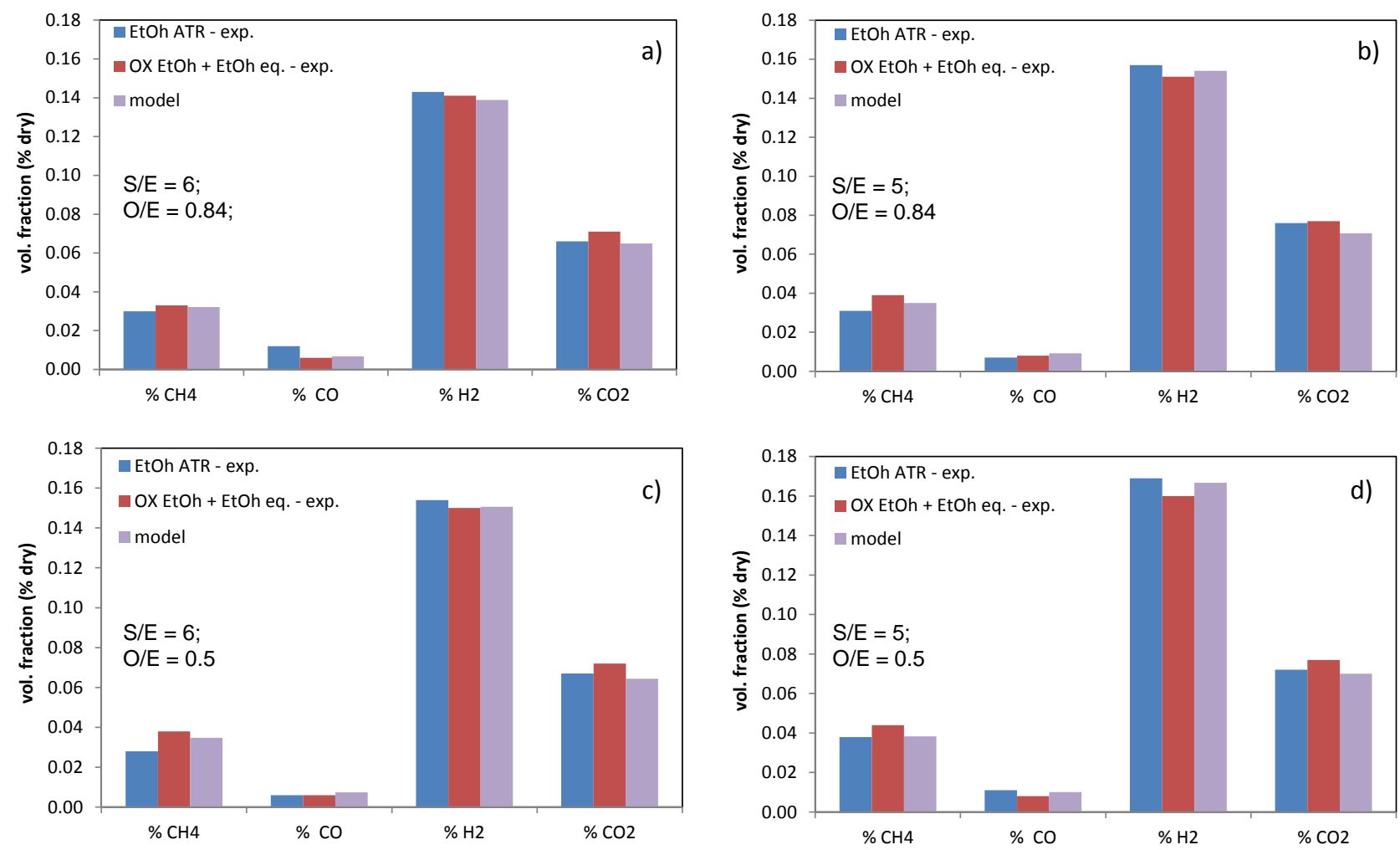

Figure 10. Model (second pathway) comparison with experimental values [56]. 


\subsection{Membranes}

Pd-Ag films are not dense when directly deposited on porous supports by PVD-MS. The $\mathrm{H}_{2} / \mathrm{N}_{2}$ ideal perm-selectivity selectivities are very low and not suitable for $\mathrm{H}_{2}$ purification. Ultra-thin $\mathrm{Pd}$ $\mathrm{Ag}$ membrane layers were also prepared by a combination of PVD-MS and ELP techniques, showing a very high $\mathrm{H}_{2}$ permeance $\left(8 \times 10^{6} \mathrm{~mol} \mathrm{~m}{ }^{2} \mathrm{~s}^{1} \mathrm{~Pa}^{1}\right.$ at $400{ }^{\circ} \mathrm{C}$ and 1 at with $\mathrm{H}_{2} / \mathrm{N}_{2}$ ideal permselectivity around 500. Detailed information and characterization of these membranes can be found in the work of Fernandez et al $[48,49]$.

The ultra thin membranes deposided by ELP showed lower compositions (ICP: Pd $=94.2 \pm 0.5$ $\% \mathrm{wt}, \mathrm{Ag}=5.8 \pm 0.5 \% \mathrm{wt}, \mathrm{EDX}: \mathrm{Pd}=92.9 \pm 0.7 \% \mathrm{wt}, \mathrm{Ag}=7.1 \pm 0.7 \% \mathrm{wt})$ than thin film membranes (EDX: $\mathrm{Pd}=85.6 \pm 1 \% \mathrm{wt}, \mathrm{Ag}=14.4 \pm 0.9 \% \mathrm{wt}$ ). The difference in the membrane composition is related to the higher silver content of the bath when plating the thin membranes.

The dependence of the Pd-Ag membrane thickness as a function of the plating time is shown in Figure 11. The orange and green points refer to the membranes prepared in references [58] and [44] respectively. The red dashed line represents a $1.0 \mu \mathrm{m} / \mathrm{h}$ metallic layer growth rate. In the zoom-in graph presented at the right bottom part, the correlation between the membrane thickness and the plating time is presented showing an almost linear dependence. Membrane thicknesses obtained with longer plating times (see orange and green dots) seems to follow this correlation. There may be a small decrease at longer plating times indicating that the membrane growth becomes somewhat slower probably due to the decrease in the concentration of the reactants along the time or to a decrease in the specific surface area for the autocatalytic Pd deposition.

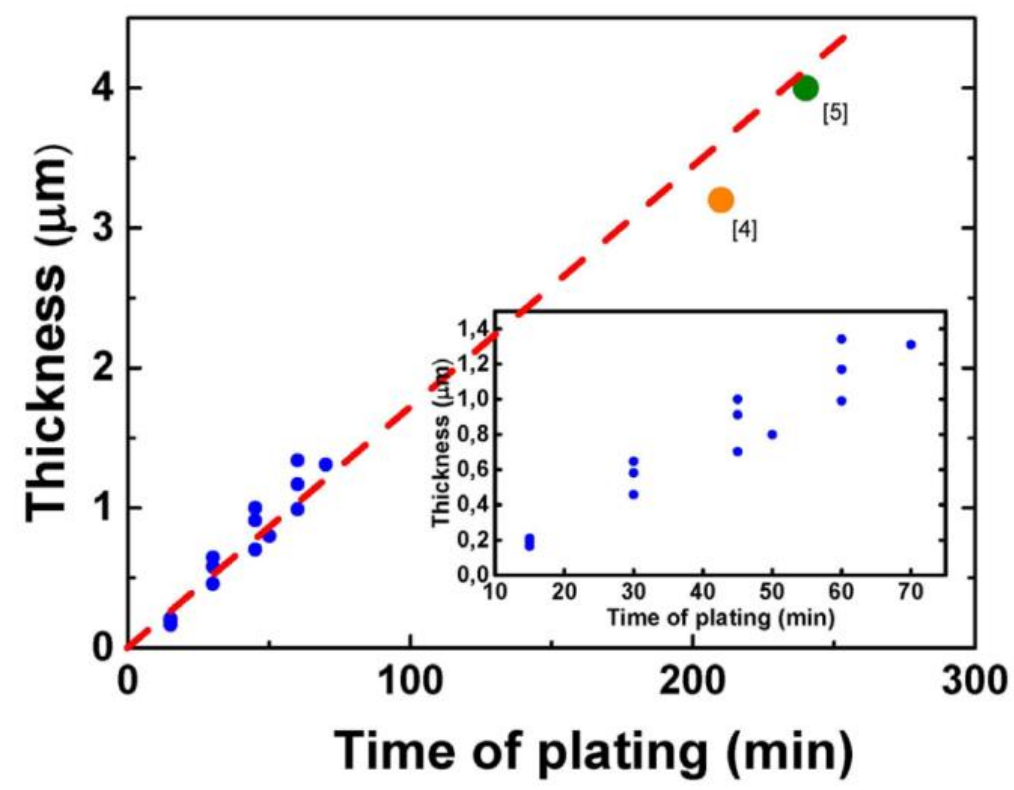

Figure 11. Pd-Ag membrane thickness as a function of the electroless plating time: blue dots (this work), orange dot reference [58], green dot reference [44] [50].

The $\mathrm{H}_{2}$ permeance and $\mathrm{H}_{2} / \mathrm{N}_{2}$ ideal perm-selectivity as a function of the membrane thickness at 400 ${ }^{\circ} \mathrm{C}$ and 1 bar transmembrane pressure difference is shown in Figure 12. The $\mathrm{H}_{2}$ permeance of the $0.46 \mu \mathrm{m}$ thick membrane is extremely high $\left(1.53 \times 10^{-5} \mathrm{~mol} \mathrm{~m}^{-2} \mathrm{~s}^{-1} \mathrm{~Pa}^{-1}\right)$ but shows a relatively low $\mathrm{H}_{2} / \mathrm{N}_{2}$ ideal perm-selectivity (close to 50). When the thickness increases from 0.46 to 1.17 or 1.29 $\mu \mathrm{m}$, the $\mathrm{H}_{2}$ permeance reduces to $0.9 \times 10^{-5} \mathrm{~mol} \mathrm{~m}^{-2} \mathrm{~s}^{-1} \mathrm{~Pa}^{-1}$. On the other hand, 1.17 and $1.29 \mu \mathrm{m}$ thick membranes showed similar hydrogen permeances. However, the $\mathrm{H}_{2} / \mathrm{N}_{2}$ ideal perm-selectivity was almost double for the thicker membrane. This may indicate that after around 1 hour of plating time the entire surface of the support was covered by a Pd-Ag layer. In these membranes, defects in the porous support are significant which can explain the difference in selectivity. Detailed information and characterization of these membranes can be found in the work of Meléndez et al [50]. 


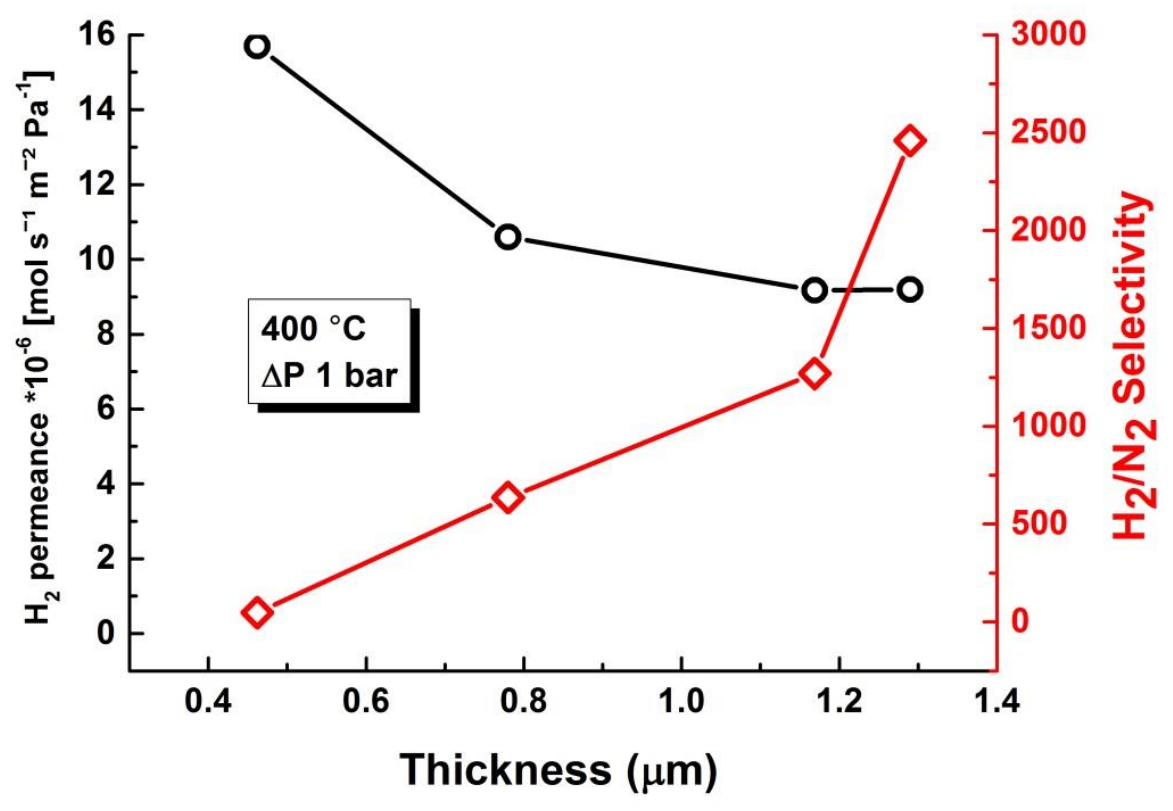

Figure 12. $\mathrm{H}_{2}$ permeance and $\mathrm{H}_{2} / \mathrm{N}_{2}$ ideal perm-selectivity as a function of the membrane thickness at $400{ }^{\circ} \mathrm{C}$ and 1 bar [50].

On the other side, single gas permeation tests of the thin membranes showed $\mathrm{H}_{2}$ permeances ( 3 to 5 $\left.\times 10-6 \mathrm{~mol} \cdot \mathrm{m}^{-2} \cdot \mathrm{s}^{-1} \cdot \mathrm{Pa}^{-1}\right)$ and ideal perm-selectivities $\left(\mathrm{H}_{2} / \mathrm{N}_{2}>10,000\right)$ at $400{ }^{\circ} \mathrm{C}$ and 1 bar higher than the target of the project. Table 3 compares the membrane permeation properties of the membrane prepared in this work with other Pd-based membranes reported in the literature. The ultra-thin membranes developed in the present work show one of the highest $\mathrm{H}_{2}$ permeances reported in the literature for supported membranes.

Table 3. Comparison of different commercial and Pd based membranes reported in the literature.

\begin{tabular}{|c|c|c|c|c|c|c|}
\hline Membrane/Support & $\begin{array}{l}\text { Thickness } \\
\qquad(\mu \mathrm{m})\end{array}$ & Method & $\begin{array}{c}\text { Temp } \\
\left({ }^{\circ} \mathrm{C}\right)\end{array}$ & $\begin{array}{c}\text { Calculated } \mathrm{H}_{2} \\
\text { Permeance } \\
\mathbf{x 1 0}^{-7} \mathrm{~mol} \mathrm{~m}^{-2} \mathrm{~s}^{-} \\
{ }^{1} \mathrm{~Pa}^{-1} \text { at } 1 \mathrm{~atm} \\
\end{array}$ & $\begin{array}{c}\mathrm{H}_{2} / \mathrm{N}_{2} \text { ideal } \\
\text { perm-selectivity }\end{array}$ & Ref. \\
\hline $\mathrm{Pd}_{77} \mathrm{Ag}_{23} / \mathrm{No}$ & $1.9-3.8$ & $\begin{array}{l}\text { PVD } 2 \\
\text { steps }\end{array}$ & 400 & 190 & 2,900 & [59] \\
\hline $\mathrm{Pd}_{77} \mathrm{Ag}_{23} /$ Micro-channels & 2.2 & $\begin{array}{l}\text { PVD } 2 \\
\text { steps }\end{array}$ & 400 & 88 & ---- & {$[60]$} \\
\hline $\mathrm{Pd}_{92}-\mathrm{Ag}_{8} / \Upsilon-\mathrm{Al}_{2} \mathrm{O}_{3} / \mathrm{YSZ}$ & 0.9 & ELP & 400 & 65 & 1,100 & {$[61]$} \\
\hline $\mathrm{Pd}-\mathrm{Au} / \mathrm{Al}_{2} \mathrm{O}_{3}$ & $2-3$ & ELP & 500 & 62 & 1,400 & {$[62]$} \\
\hline Pd-Au/YSZ-PSS & $1-5$ & ELP & 400 & $43-52$ & $\begin{array}{c}10,000-20,000 \\
\left(\mathrm{H}_{2} / \mathrm{Ar}\right)\end{array}$ & {$[63]^{1}$} \\
\hline $\mathrm{Pd}_{85}-\mathrm{Ag}_{15} / \alpha-\mathrm{Al}_{2} \mathrm{O}_{3}$ & 4 & ELP & 400 & 42 & 20,000 & {$[64]$} \\
\hline $\mathrm{Pd}_{85}-\mathrm{Ag}_{15} / \alpha-\mathrm{Al}_{2} \mathrm{O}_{3}$ & 3.2 & ELP & 400 & 31 & $8,000-10,000$ & {$[58]$} \\
\hline $\mathrm{Pd}-\mathrm{Ag} / \alpha-\mathrm{Al}_{2} \mathrm{O}_{3}$ & 2 to 10 & ELP & 350 & $6-31$ & 500 to $>1,000$ & {$[65]^{1}$} \\
\hline $\mathrm{Pd} / \Upsilon-\mathrm{Al}_{2} \mathrm{O}_{3}$ & $2-4$ & ELP & 400 & 27 & 500 & [66] \\
\hline $\mathrm{Pd} /$ Metallic & 3 to 5 & ELP & 450 & 20 & $450 \mathrm{H}_{2} / \mathrm{He}$ & {$[67]^{1}$} \\
\hline $\mathrm{Pd}-\mathrm{Ru} / \mathrm{Al}_{2} \mathrm{O}_{3}-\mathrm{PSS}$ & 6.4 & ELP & 400 & 19 & 15,000@10bar & {$[68]^{1}$} \\
\hline $\mathrm{Pd}-\mathrm{Ag} / \alpha-\mathrm{Al}_{2} \mathrm{O}_{3}$ & 3 to 9 & ELP & 350 & 15 & $>7,600$ & {$[69]^{1}$} \\
\hline Pd/Metallic & 12 & PVD-ELP & 417 & 11 & 1,100 & {$[70]$} \\
\hline $\mathrm{Pd} /$ Metallic & 7.6 & & 450 & 9 & Infinite, after & {$[67]^{1}$} \\
\hline
\end{tabular}




\begin{tabular}{|c|c|c|c|c|c|c|}
\hline & & & & \multicolumn{3}{|c|}{$3,500 \mathrm{~h}>6000$} \\
\hline $\mathrm{Pd} / \mathrm{No}$ & 76 & $\begin{array}{c}\text { Self- } \\
\text { supported }\end{array}$ & 600 & 4 & $\begin{array}{c}\mathrm{H}_{2} / \mathrm{He} \\
>>10000\end{array}$ & {$[71]^{1}$} \\
\hline $\mathrm{Pd}_{85}-\mathrm{Ag}_{15} / \alpha-\mathrm{Al}_{2} \mathrm{O}_{3} / \mathrm{ZrO}_{2}$ & 4 & ELP & 400 & 38 & $>10,000$ & {$[44]$} \\
\hline $\mathrm{Pd}_{85}-\mathrm{Ag}_{15} /$ Metallic & $4-5$ & ELP & 400 & 10 & $>200,000$ & $\begin{array}{l}{[45]} \\
{[48]}\end{array}$ \\
\hline $\mathrm{PdAg} / \mathrm{ZO}_{2}$ & 1 & PVD+ELP & 400 & 80 & 500 & $\begin{array}{l}\text { This } \\
\text { work }\end{array}$ \\
\hline $\mathrm{Pd}_{91}-\mathrm{Ag}_{9} / \mathrm{Al} 2 \mathrm{O} 3$ & 0.46 & ELP & 400 & 157 & 48 & \\
\hline $\mathrm{Pd}_{92.8}-\mathrm{Ag}_{7.2} / \mathrm{Al} 2 \mathrm{O} 3$ & 0.78 & ELP & 400 & 106 & 636 & {$[50]$} \\
\hline $\mathrm{Pd}_{94.3}-\mathrm{Ag}_{5.7} / \mathrm{Al} 2 \mathrm{O} 3$ & 1.17 & ELP & 400 & 91.7 & 1270 & work \\
\hline $\mathrm{Pd}_{92.8}-\mathrm{Ag}_{7.2} / \mathrm{Al} 2 \mathrm{O} 3$ & 1.29 & ELP & 400 & 91.9 & 2460 & \\
\hline
\end{tabular}

(1) Commercial Pd based membranes.

\subsubsection{Long term stability}

The $1.29 \mu \mathrm{m}$ thick membrane was tested for $1000 \mathrm{~h}$ at $400{ }^{\circ} \mathrm{C}$ and 1 bar pressure difference in order to assess its long-term performance. The $\mathrm{H}_{2}$ and $\mathrm{N}_{2}$ flow rates were monitored over time in order to determine the evolution of the $\mathrm{H}_{2}$ permeance and the $\mathrm{H}_{2} / \mathrm{N}_{2}$ ideal perm-selectivity as presented in Figure 13. The reactor was fed with air for two minutes to carry out the activation of the selective layer. After the activation, the membrane showed a $\mathrm{H}_{2}$ permeance of 9.0-9.4 $\times 10^{-6} \mathrm{~mol} \mathrm{~m}^{-2} \mathrm{~s}^{-1} \mathrm{~Pa}^{-1}$. Nitrogen suffered a small increase in its permeance too. During the first 400 hours, and after activation step, the $\mathrm{H}_{2}$ permeance kept a constant value with a constant $\mathrm{H}_{2} / \mathrm{N}_{2}$ ideal perm-selectivity of $\sim 2460$. After this period, another small increase in nitrogen was detected. This small increase in the nitrogen permeation is probably related to damaging of the membrane sealing, leading to the aforementioned issue (measure in Helium - ethanol leak test after the long term stability test). Afterward, the nitrogen permeation maintained constant until the end of the 1000 hours of operation with a constant $\mathrm{H}_{2} / \mathrm{N}_{2}$ ideal perm-selectivity of 1900 .

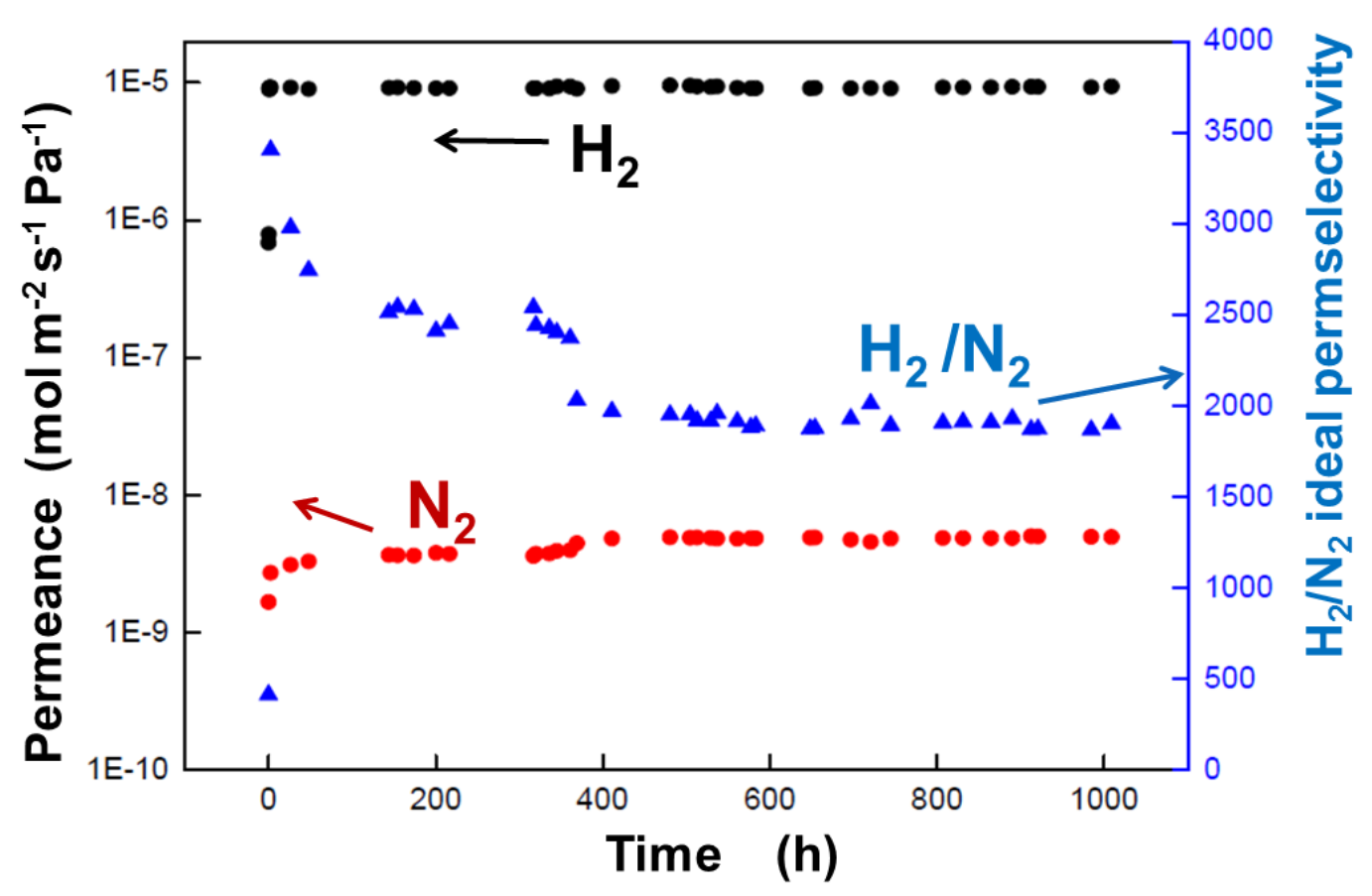

Figure 13. $\mathrm{H}_{2}$ and $\mathrm{N}_{2}$ long-term permeances $\left(\mathrm{mol} \mathrm{m}^{-2} \mathrm{~s}^{-1} \mathrm{~Pa}^{-1}\right)$ and $\mathrm{H}_{2} / \mathrm{N}_{2}$ ideal perm-selectivity of the $1.29 \mu \mathrm{m}$ thick membrane at $400{ }^{\circ} \mathrm{C}$ and 1 bar pressure difference [50]. 


\subsubsection{Membranes for the prototype}

Thin film $(\sim 4 \mu \mathrm{m}) \mathrm{Pd}-\mathrm{Ag}$ membranes developed by direct simultaneous Pd and Ag electroless plating (ELP) has been selected for the prototype. Selective layers are deposited onto alumina 50 $\mathrm{cm}$ long porous tubes with thicker wall $(10 / 4 \mathrm{~mm}$ o.d./i.d., provided by Rauschert Kloster Veilsdorf) to improve the mechanical properties compared to the 10/7 mm o.d./i.d. supports. First batch of membranes has been already manufactured (see Figure 14). The complete set of membranes and spare parts will be delivered by end of November 2016.

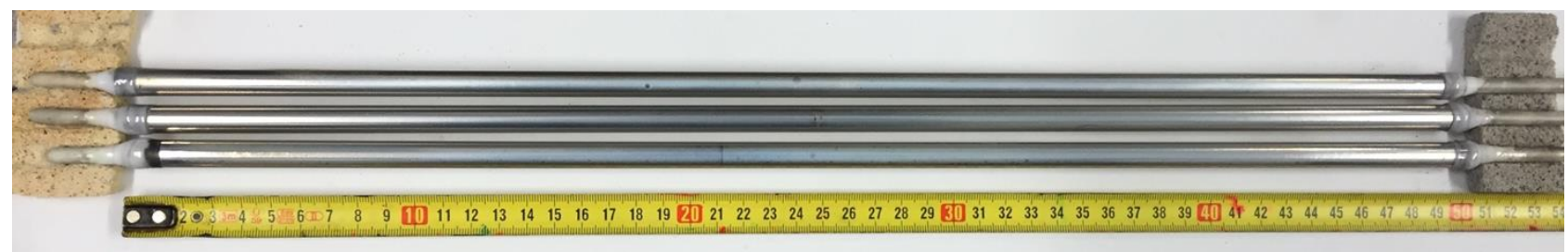

Figure 14. Membranes for the prototype.

\subsection{Lab scale reactors (reaction measurements).}

The authothermal reforming of ethanol has been carried out in the experimental setup described above. The oxygen-to-ethanol ratio is set to be 0.4 , to assess the method of converting a feed mixture of ethanol, water and air to an equivalent composition of $\mathrm{CO}, \mathrm{CO}_{2}, \mathrm{H}_{2} \mathrm{O}$, and $\mathrm{CH}_{4}$. The operating temperatures for these experiments were again set to be 450,500 and $550{ }^{\circ} \mathrm{C}$. The operating pressures for these experiments were also again set to be 2,3 , and 4 bar(a). In the following figure a comparison between the experimental results and model prediction is reported.

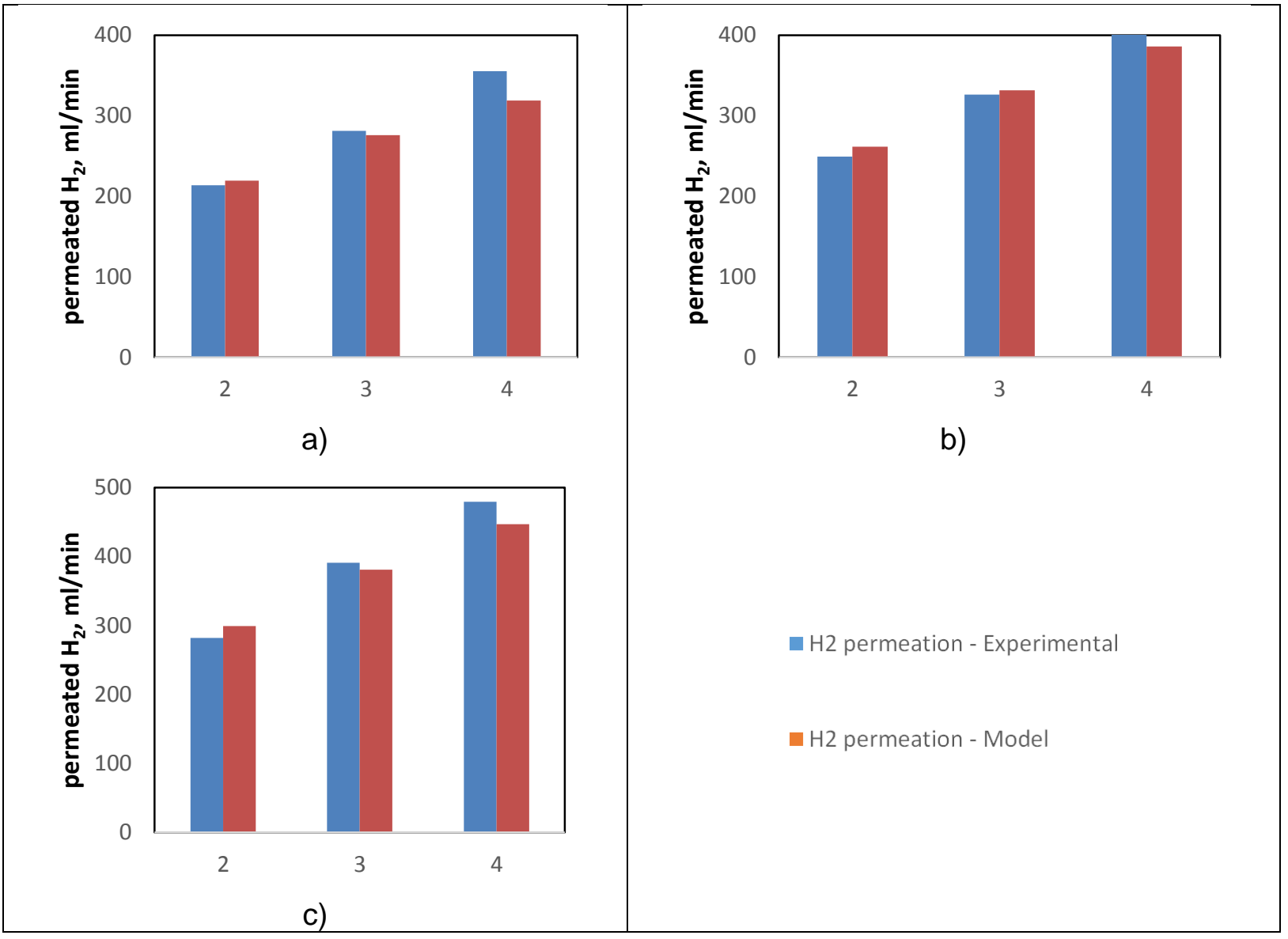

Figure 15. Hydrogen permeation, model vs. experimental results at a) $450{ }^{\circ} \mathrm{C}$, b) $500{ }^{\circ} \mathrm{C}$, and c) $550{ }^{\circ} \mathrm{C}$ by varying feed pressure on the $x$-axis. 
From the three graphs above we can observe that the hydrogen permeation increases significantly, at higher temperatures. In general the model reported above is able to describe the observed experimental results.

The hydrogen recovery factor (HRF) at 4 bar(a) during these standard experiments are tabulated in Table 4. From the table we can clearly observe an increasing trend of the $\mathrm{HRF}^{1}$ with increasing temperature. At which the HRF is defined as the maximum pure hydrogen obtained relatively from the ethanol present after combustion. This is mainly due to the higher methane conversion at higher temperatures, which enables more hydrogen to permeate through the membrane.

Table 4. Hydrogen recovery factor (HRF) versus Temperature

\begin{tabular}{ccc}
\hline $\begin{array}{c}\text { Temperature } \\
{ }^{\circ} \mathbf{C}\end{array}$ & $\begin{array}{c}\text { Feed Pressure } \\
\left(\mathbf{b a r}_{\mathbf{a}}\right)\end{array}$ & $\begin{array}{c}\text { HRF } \\
(\boldsymbol{\%})\end{array}$ \\
\hline 450 & 4 & 27.5 \\
500 & 4 & 34.9 \\
550 & 4 & 46.4 \\
\hline
\end{tabular}

\subsection{Membrane reformer prototype}

A membrane reactor was designed for an output of $3.2 \mathrm{Nm}^{3} / \mathrm{h}$ with a Hydrogen Recovery Factor (HRF) of $76.8 \%$. The reactor design employs 37 tubular membranes of $40 \mathrm{~cm}$ length. The compact design aims to meet the targets for efficient hydrogen production either as a stand-alone reactor or integrated within the micro-CHP system.

Operating conditions of the reactor are 12 bar(a) at $500{ }^{\circ} \mathrm{C}$. Hydrogen permeation through the membranes is enhanced by the use of steam as sweep gas on the permeate side of the membranes. The reactor is designed to operate at partial feed load down to $40 \%$ of its nominal value. Nominal feed conditions consider a water to ethanol ratio (molar) of 3.6 and oxygen to ethanol ratio of 0.43 .

A view of the fuel processor under construction is shown in Figure 16. Once assembled functionality tests will be performed on this prototype before integration into PEM fuel Cell CHPsystem.

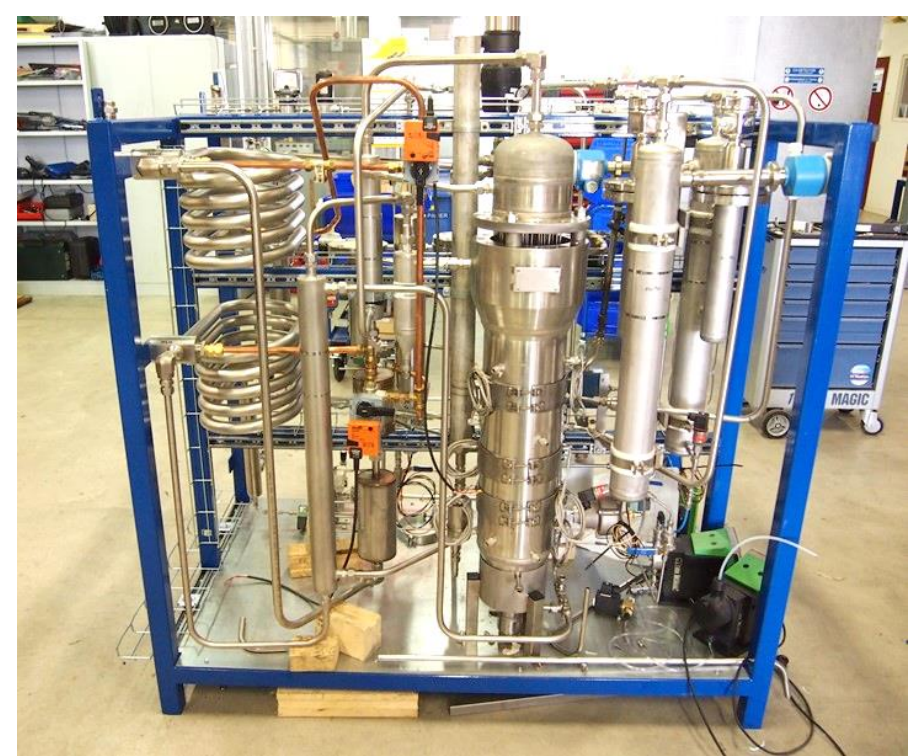

Figure 16. Skid with fuel processor.

${ }^{1} \mathrm{HRF}=\frac{\left(\mathrm{H}_{2, \text { permeated }}\right)}{\left(6 \mathrm{C}_{2} \mathrm{H}_{5} \mathrm{OH}-2 \mathrm{O}_{2}\right)}$ 


\section{Conclusions}

The Fluidcell project is developing an ethanol autothermal reforming prototype for hydrogen production for fuel cell applications. the results summarized in this paper, briefly report the development of new catalysts for fluidized bed applications that has been tested under reactive conditions in a fluidized bed membrane reactor. The kinetic model developed for this catalyst matches very well the results of the experiments carried out in a lab scale prototype.

New membranes with high flux and high selectivities have been developed and scaled up. These membranes have been integrated at lab scale ( 5 short membranes in a single reactor) obtaining up to $66 \%$ hydrogen recovery and high hydrogen purity.

According to these results a prototype (with 37 longer membranes) has been designed and built and is currently being assambled for the final field tests.

\section{Acknowledgements}

The research leading to these results has received funding from the European Union's Seventh Framework Programme (FP7/2007-2013) for the Fuel Cells and Hydrogen Joint Technology Initiative under grant agreement $n^{\circ}$ 621196. This work is also partly funded by the MEMPORE project (Development of novel nanostructured membranes for micro-cogeneration (m-CHP)) (PI_2014_1_25) from the Basque Department of Education, Language Policy and Culture. Finally, one of the authors would like to thank the University of Basque Country (UPV-EHU) for Zabalduz scholarship program.

Disclosure: The present publication reflects only the author's views and the FCH JU and the Union are not liable for any use that may be made of the information contained therein

$\begin{array}{ll}\text { Abbreviations } \\ \text { ATR } & \text { Autothermal reformer } \\ \text { ATR-MR } & \text { Autothermal membrane reformer } \\ \text { BoP } & \text { Balance of plant } \\ \text { CFR } & \text { Carbon formation rate } \\ \text { CHP } & \text { Combined heat and power } \\ \text { ELP } & \text { Electroless plating } \\ \text { ESR } & \text { Ethanol steam reforming } \\ \text { FBR } & \text { Fluidized bed reactor } \\ \text { FBMR } & \text { Fluidized bed membrane reactor } \\ \text { FC } & \text { Fuel cell } \\ \text { FP7 } & \text { Seventh Framework Programme } \\ \text { GHSV } & \text { Gas hourly space velocity } \\ \text { HHV } & \text { High heating value } \\ \text { HRF } & \text { H } 2 \text { recovery factor } \\ \text { HT-WGS } & \text { High temperature water gas shift } \\ \text { HX } & \text { heat exchanger } \\ \text { ICP-OES } & \text { Inductively coupled plasma optical emission spectrometry } \\ \text { ID } & \text { Inside diameter } \\ \text { IMDBL } & \text { Inter-metallic diffusion barrier layer } \\ \text { kW } & \text { kilowatt } \\ \text { LHV } & \text { Low heating value } \\ \text { LT-WGS } & \text { Low temperature water gas shift } \\ \text { m-CHP } & \text { Micro Combined Heat and Power } \\ & \end{array}$




\begin{tabular}{|c|c|}
\hline MEA & Membrane electrode assembly \\
\hline METH & Methanator. \\
\hline MR & Membrane reactor \\
\hline $\mathrm{O} / \mathrm{C}$ & Oxigen-to-carbon ratio \\
\hline OD & outside diameter \\
\hline PEM & Polymer electrolyte membrane type \\
\hline PEMFC & Polymer electrolyte membrane fuel cell \\
\hline PEM m-CHP & Polymer electrolyte membrane fuel cell micro combined heat and power \\
\hline PROX & Preferential oxidation \\
\hline PSS & Porous stainless steel \\
\hline PVD-MS & Physical vapour deposition magnetron sputerring \\
\hline SR & Steam reforming \\
\hline SMR & steam methane reforming \\
\hline $\mathrm{S} / \mathrm{C}$ & Steam-to-Carbon ratio \\
\hline TEM & Transmission electron microscopy \\
\hline TPO & Temperature programmed oxidation \\
\hline $\mathrm{u}$ & fluidization velocity \\
\hline $\mathrm{u}_{\mathrm{mf}}$ & minimum fluidization velocity \\
\hline WGS & Water gas shift \\
\hline WHSV & Weight hourly space velocity \\
\hline $\mathrm{W} / \mathrm{EtOH}$ & Water ethanol ratio \\
\hline XRD & $\mathrm{X}$-ray diffraction \\
\hline 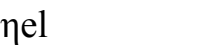 & Net electric efficiency \\
\hline
\end{tabular}

\section{References}

[1]Future of Rural Energy in Europe (FREE) http://www.rural-energy.eu/en_GB/rural-energy\#.VTnANKa0dV; 2016 [accessed 01-10-16].

[2]United Nations. http://www.un.org/en/development/desa/news/population/world-urbanizationprospects-2014.html; 2014 [accessed 01-10-16].

[3]European Commission. A policy framework for climate and energy in the period from 2020 to 2030 [COM(2014) 15]. https://ec.europa.eu/energy/en/topics/energy-strategy/2030-energy-strategy; 2014 [accessed 01.09.14].

[4]Advancing Europe's energy system: Stationary fuel cell in distributed generation, FCH JU, Luxemburg Publications Office of the European Union, Luxemburg, 2015. ISBN 978-92-9246-134-8, DOI 10.2843/088142. Available online: http://www.fch.europa.eu/studies [accessed 31-03-16].

[5]Parliament European. Directive 2012/27/EU of the European parliament and of the council of 25 October 2012 on energy efficiency. Off J Eur Union Dir 2012:1-56, http://eurlex.europa.eu/LexUriServ/LexUriServ.do?uri=OJ:L:2012:315:0001:0056:en:PDF [accessed 01-1016].

[6] Alanne K, Saari A. Sustainable small-scale CHP technologies for buildings: the basis for multiperspective decision-making. Renewable and Sustainable Energy Reviews 2004;8:401-431, http://dx.doi.org/10.1016/j.rser.2003.12.005.

[7] Campanari S, Macchi E, Manzolini G. Membrane reformer PEM cogeneration systems for residential applications - Part B: Techno-economic analysis and system layout. Asia-Pac J Chem Eng 2009;4:311-321, http://dx.doi.org/10.1002/apj.247.

[8] Elmer T, Worall M, Wu S, Riffat SB. Fuel cell technology for domestic built environment applications: State of-the-art review. Renew Sustain Energy Rev 2015;42:913-931. http://dx.doi.org/10.1016/j.rser.2014.10.080.

[9] Dodds PE, Staffell I, Hawkes AD, Li F, Grünewald P, McDowall W. Hydrogen and fuel cell technologies for heating: A review. Int J Hydrog Energy 2015;40:2065-2083. http://dx.doi.org/10.1016/j.ijhydene.2014.11.059. 
[10] Renewable Fuels Association. Ethanol industry outlook. 2016. http://ethanolrfa.org/resources/publications/outlook/ [accessed 01-10-16].

[11] Gallucci F, Fernandez E, Corengia P, van Sint Annaland M. Recent advances on membranes and membrane reactors for hydrogen production. Chem Eng Sci 2013;92:40-66. http://dx.doi.org/10.1016/j.ces.2013.01.008.

[12] Doukelis A, Panopoulos K, Koumanakos A, Kakaras E, editors. Palladium Membrane technology for Hydrogen Production, Carbon capture and Other Applications. 1st ed. Amsterdam: Woodhead Publishing; 2015.

[13] Gallucci F, Comite A, Capannelli G, Basile A. Steam Reforming of Methane in a Membrane Reactor: An Industrial Case Study. Ind Eng Chem Res 2006;45:2994-3000. http://dx.doi.org/10.1021/ie058063j.

[14] Barbieri G, Brunetti A, Caravella A, Drioli E. Pd-based membrane reactors for one-stage process of water gas shift. RSC Adv 2011;1:651-661. http://dx.doi.org/10.1039/c1ra0037e.

[15] Brunetti A, Drioli E, Barbieri G. Energy and mass intensities in hydrogen upgrading by a membrane reactor. Fuel Process Technol 2014;118:278-286. http://dx.doi.org/10.1016/j.fuproc.2013.09.009.

[16] Deshmukh SARK, Heinrich S, Mörl L, van Sint Annaland M, Kuipers JAM. Membrane assisted fluidized bed reactors: Potentials and hurdles. Chem Eng Sci 2007;62:416-436. http://dx.doi.org/10.1016/j.ces.2016.08.062.

[17] Lin WH, Chang HF. A study of ethanol dehydrogenation reaction in a palladium membrane reactor. Catal Today 2004;97:181 -188, SPEC. ISS.

[18] Lin WH, Liu YC, Chang HF. Hydrogen production from oxidative steam reforming of ethanol in a palladium-silver alloy composite membrane reactor. J Chin Inst Chem Eng 2008;39:435-440.

[19] Tosti S, Basile A, Borelli R, Borgognoni F, Castelli S, Fabbricino M et al. Ethanol steam reforming kinetics of a Pd-Ag membrane reactor. Int J Hydrogen Energy 2009;34:4747-4754.

[20] Gallucci F, van Sint Annaland M, Kuipers JAM. Pure hydrogen production via autothermal reforming of ethanol in a fluidized bed membrane reactor. Int J Hydrogen Energy 2010a;35:16591668 .

[21] Roses L, Gallucci F, Manzolini G, Campanari S, van Sint Annaland M. Comparison between fixed bed and fluidized bed membrane reactor configurations for PEM based micro-cogeneration systems. Chemical Engineering Journal 2011;171:1415-1427.

[22] Dorer V, Weber R, Weber A. Performance assessment of fuel cell micro-cogeneration systems for residential buildings. Energy Build 2005;37:1132-1146. doi:10.1016/j.enbuild.2005.06.016.

[23] Campanari S, Macchi E, Manzolini G. Innovative membrane reformer for hydrogen production applied to PEM micro-cogeneration: Simulation model and thermodynamic analysis. Int J Hydrogen Energy 2008;33:1361-1373. doi:10.1016/j.ijhydene.2007.12.041.

[24] Xie D, Wang Z, Jin L, Zhang Y. Energy and exergy analysis of a fuel cell based micro combined heat and power cogeneration system. Energy Build 2012;50:266-272. doi:10.1016/j.enbuild.2012.03.047.

[25] Giunta P, Mosquera C, Amadeo N, Laborde M. Simulation of a hydrogen production and purification system for a PEM fuel-cell using bioethanol as raw material. J Power Sources 2007;164:336-343. doi:10.1016/j.jpowsour.2006.09.091.

[26] Benito M, Padilla R, Sanz JL, Daza L. Thermodynamic analysis and performance of a $1 \mathrm{~kW}$ bioethanol processor for a PEMFC operation. J Power Sources 2007;169:123-130. doi:10.1016/j.jpowsour.2007.02.001

[27] Francesconi JA, Mussati MC, Mato RO, Aguirre PA. Analysis of the energy efficiency of an integrated ethanol processor for PEM fuel cell systems. J Power Sources 2007;167:151-161. doi:10.1016/j.jpowsour.2006.12.109. 
[28] Francesconi JA, Mussati MC, Aguirre PA. Effects of PEMFC operating parameters on the performance of an integrated ethanol processor. Int J Hydrogen Energy 2010;35:5940-5946. doi:10.1016/j.ijhydene.2009.12.103.

[29] Manzolini G, Tosti S. Hydrogen production from ethanol steam reforming: energy efficiency analysis of traditional and membrane processes. Int J Hydrogen Energy 2008;33:5571-5582. doi:10.1016/j.ijhydene.2008.06.029.

[30] Foresti S, Manzolini G. Performances of a micro-CHP system fed with bio-ethanol based on fluidized bed membrane reactor and PEM fuel cells. Int J Hydrogen Energy 2016;41:9004-9021. http://dx.doi.org/10.1016/j.ijhydene.2016.03.210.

[31] Siang J, Lee C, Wang C, Wang W, Deng C, Yeh C et al. Int J Hydrogen Energ 2010;35:3456-3462.

[32] Ciambelli P, Palma P, Ruggiero A. Appl Catal B: Environ 2010;96:190-197.

[33] Hou T, Zhang S, Chen Y, Wang D, Cai W. Hydrogen production from ethanol reforming: catalyst and reaction mechanism. Renewable and Sustainable Energy Reviews 2015;44:132-148.

[34] Sun J, Karim A, Mei D, Engelhard M, Bao X, Wang Y, Appl Catal B: Environ 2015;162:141-148.

[35] El Doukkali M, Iriondo A, Arias PL, Cambra JF, Gandarias I, Barrio VL. Bioethanol/glycerol mixture steam reforming over Pt and PtNi supported on lanthana or ceria doped alumina catalysts. Int J Hydrogen Energy 2012;37: 8298-8309. doi:10.1016/j.ijhydene.2012.02.154.

[36] Sanchez-Sanchez MC, Navarro Yerga RM, Kondarides DI, Verykios XE, Fierro JLG. Mechanistic aspects of the ethanol steam reforming reaction for hydrogen production on $\mathrm{Pt}, \mathrm{Ni}$, and $\mathrm{PtNi}$ catalysts supported on gamma- $\mathrm{Al}_{2} \mathrm{O}_{3}$. J Phys Chem A 2010;114:3873-3882. doi:10.1021/jp906531x.

[37] Pérez-Hernández R, Mondragón Galicia G, Mendoza Anaya D, Palacios J, Angeles-Chavez C, Arenas-Alatorre J. Synthesis and characterization of bimetallic $\mathrm{Cu}-\mathrm{Ni} / \mathrm{ZrO}_{2}$ nanocatalysts: $\mathrm{H}_{2}$ production by oxidative steam reforming of methanol. Int J Hydrogen Energy 2008;33:4569-4576. doi:10.1016/j.ijhydene.2008.06.019.

[38] Palma V, Castaldo F, Ciambelli P, Iaquaniello G, Capitani G. On the activity of bimetallic catalysts for ethanol steam reforming. Int J Hydrogen Energy 2013;38:6633-6645

[39] Palma V, Castaldo F, Ciambelli P, Iaquaniello G. Steam Reforming of Ethanol to $\mathrm{H}_{2}$ over Bimetallic Catalysts: Crucial Roles of $\mathrm{CeO}_{2}$, Steam-to-Carbon Ratio and Space Velocity. Chemical Engineering Transactions 2013;35:1369-1374. DOI:10.3303/CET1335228.

[40] Rotaru CG, Postole G, Florea M, Matei-Rutkovska F, Pârvulescu VI, Gelin P. Appl Catal A: Gen 2015;494:29-40.

[41] Di Monte R. Kašpar J. Nanostructured $\mathrm{CeO}_{2}-\mathrm{ZrO}_{2}$ mixed oxides. J Mater Chem 2005;15:633-648.

[42] Guzman J, Carrettin S, Corma A. Spectroscopic Evidence for the Supply of Reactive Oxygen during $\mathrm{CO}$ Oxidation Catalyzed by Gold Supported on Nanocrystalline $\mathrm{CeO}_{2}$. J Am Chem Soc 2005; 127:3286-3287. 10.1021/ja043752s

[43] Palma V, Ruocco C, Meloni E, Ricca A. Oxidative steam reforming of ethanol on mesoporous silica supported $\mathrm{Pt}-\mathrm{Ni} / \mathrm{CeO}_{2}$ catalysts. International Journal of Hydrogen Energy 2016; http://dx.doi.org/10.1016/j.ijhydene.2016.05.071

[44] Fernandez E, Coenen K, Helmi A, Melendez J, Zuñiga J, Tanaka DAP et al. Preparation and characterization of thin-film $\mathrm{Pd}-\mathrm{Ag}$ supported membranes for high-temperature applications. Int $\mathrm{J}$ Hydrogen Energy 2015;40:13463-13478.

[45] Fernandez E, Medrano JA, Melendez J, Parco M, Viviente JL, van Sint Annaland M, et al. Preparation and characterization of metallic supported thin $\mathrm{Pd}-\mathrm{Ag}$ membranes for hydrogen separation. Chem Eng J 2015 Available online 10 November 2015. http://dx.doi.org/10.1016/j.cej.2015.09.119. 
[46] Medrano JA, Fernandez E, Melendez J, Parco M, Pacheco Tanaka DA, van Sint Annaland M et al. Pd-based metallic supported membranes: High-temperature stability and fluidized bed reactor testing. Int J Hydrogen Energy 2016;41:8706-8718.

[47] Pacheco Tanaka DA, Llosa Tanco MA, Niwa S, Wakui Y, Mizukami F, Namba T, et al.

Preparation of palladium and silver alloy membrane on a porous $\alpha$-alumina tube via simultaneous electroless plating. J Memb Sci 2005;247:21-27. doi:10.1016/j.memsci.2004.06.002.

[48] Fernandez E, Sanchez-García JA, Melendez J, Spallina V, van Sint Annaland M, Gallucci F, et al. Development of highly permeable ultra-thin Pd-based supported membranes. Chem Eng J 2016;305:149-155. http://dx.doi.org/10.1016/j.cej.2015.11.060.

[49] Fernandez E, Sanchez-García JA, Viviente JL, van Sint Annaland M, Gallucci F, Pacheco Tanaka DA. Morphology and $\mathrm{N}_{2}$ Permeance of Sputtered Pd-Ag Ultra-Thin Film Membranes. Molecules 2016;21:210; doi:10.3390/molecules21020210.

[50] Meléndez J, Pacheco Tanaka DA, Fernandez E, Gallucci F, van Sint Annaland M, Arias PL. Preparation and characterization of ceramic supported ultra-thin $(\sim 1 \mu \mathrm{m})$ Pd-Ag membranes. Submitted to Journal of Membrane Science 2016.

[51] Deshmane VG, Abrokwah RY, Kuila D. Synthesis of stable Cu-MCM-41 nanocatalysts for $\mathrm{H}_{2}$ production with high selectivity via steam reforming of methanol. Int $\mathrm{J}$ Hydrogen Energy 2015;40:10439-10452.

[52] Kugai J, Subramani V, Song C, Engelhard MH, Chin YH. J Catal 2006;238:430-440.

[53] Vizcaíno AJ, Carrero A, Calles JA. Hydrogen production by ethanol steam reforming over CuNi supported catalysts. Int J Hydrogen Energy 2007;32:1450-61.

[54] Chen H, Yu H, Peng F, Yang G, Wang H, Yang J, et al. Autothermal reforming of ethanol for hydrogen production over perovskite $\mathrm{LaNiO}_{3}$. Chem Eng J 2010;160:333-9.

[55] Srisiriwat N, Therdthianwong S, Therdthianwong A. Oxidative steam reforming of ethanol over $\mathrm{Ni} / \mathrm{Al}_{2} \mathrm{O}_{3}$ catalysts promoted by $\mathrm{CeO}_{2}, \mathrm{ZrO}_{2}$ and $\mathrm{CeO}_{2}-\mathrm{ZrO}_{2}$. Int $\mathrm{J}$ Hydrogen Energy 2009;34:2224e34.

[56] Ruocco C, Meloni E, Palma V, van Sint Annaland M, Spallina V, Gallucci F. Pt-Ni based catalyst for ethanol reforming in a fluidized bed membrane reactor. Int J Hydrogen Energy 2016; http://dx.doi.org/10.1016/j.ijhydene.2016.08.045.

[57] Palma V, Ruocco C, Ricca A. Ceramic foams coated with $\mathrm{PtNi} / \mathrm{CeO}_{2} \mathrm{ZrO}_{2}$ for bioethanol steam reforming. Int J Hydrogen Energy 2016;41:11526-11536. http://dx.doi.org/10.1016/j.ijhydene.2016.04.028

[58] Fernandez E, Helmi A, Coenen K, Melendez J, Viviente JL, Pacheco Tanaka DA, et al. Development of thin $\mathrm{Pd}-\mathrm{Ag}$ supported membranes for fluidized bed membrane reactors including WGS related gases. Int J Hydrogen Energy 2015;40:3506-3519.

[59] Peters TA, Stange M, Bredesen M. On the high pressure performance of thin supported Pd-23\%Ag membranes-Evidence of ultrahigh hydrogen flux after air treatment. $\mathrm{J}$ Memb Sci 2011;378:28-34. http://dx.doi.org/10.1016/j.memsci.2010.11.022.

[60] Vicinanza N, Svenum IH, Næss LN, Peters TA, Bredesen R, Borg A, et al. Thickness dependent effects of solubility and surface phenomena on the hydrogen transport properties of sputtered Pd77\%Ag23\% thin film membranes. J Memb Sci 2015;476:602-608. http://dx.doi.org/10.1016/j.memsci.2014.11.031.

[61] Pacheco Tanaka DA, Okazaki J, Llosa Tanco MA, Suzuki TM. 5 - Fabrication of supported palladium alloy membranes using electroless plating techniques. In: Doukelis A, Panopoulos K, Koumanakos A, Kakaras E, editors. Palladium Membrane technology for Hydrogen Production, Carbon capture and Other Applications, 1st ed., Amsterdam: Woodhead Publishing; 2015, p. 8399.

[62] Shi L, Goldbach A, Xu H. High-flux $\mathrm{H}_{2}$ separation membranes from ( $\left.\mathrm{Pd} / \mathrm{Au}\right)$ n nanolayers. Int J Hydrogen Energy 2011;36:2281-2284. doi:10.1016/j.ijhydene.2010.11.056. 
[63] Damle A, Acquaviva J. Membrane Reactor for Hydrogen Production. AlChE 2008 Annual meeting, Philadelphia, PA. Available online: http://www.pall.com/pdfs/OEM-Media-Membranesand-Materials/Hydrogen_Reactor_for_Hydrogen_Production.pdf [accessed 12-09-16].

[64] Helmi A, Fernandez E, Melendez J, Pacheco Tanaka DA, Gallucci F, van Sint Annaland M. Fluidized Bed Membrane Reactors for Ultra Pure $\mathrm{H}_{2}$ Production-A Step forward towards Commercialization. Molecules 2016;21:376-394. doi:10.3390/molecules21030376.

[65] Media and process Technology Inc.. Available online: http://www.mediaandprocess.com/products/products02.html [accessed 12-09-13-16].

[66] Goldbach A, Bao F, Qi C, Bao C, Zhao L, Hao C, et al. Evaluation of Pd composite membrane for pre-combustion $\mathrm{CO}_{2}$ capture. Int $\mathrm{J}$ Greenh Gas Control 2015;33:69-76. doi:10.1016/j.ijggc.2014.12.003.

[67] Veenstra P, Iyer M, Nijmeijer A, Geuzebroek F, Moene R, Saukaitis J. Integrated Approach to $\mathrm{CO}_{2}$ Capture: Fuel Gas Decarbonisation. Energy Procedia 2014;63:2054-2059. doi:10.1016/j.egypro.2014.11.221.

[68] Li A; Boyd T, Gulamhusein A, Mahecha-Botero A, Grace J, Lim J, et al. Towards Industrial Applications: Membrane and Fluidized Bed Reactor Research at MRT and NORAM. In Proceedings of ECN Workshop on Pd-Membrane Technology Scale-Up, Petten, The Netherlands, 20-21 November 2014.

[69] Hysep: ECN, Hydrogen Seperation Modules. Available online: http://www.hysep.com/fileadmin/hysep/user/documents/B-09-010-hysep.pdf [accessed 12-10-16].

[70] Dittmar B, Behrens A, Schödel N, Rüttinger M, Franco T, Straczewski G, et al. Methane steam reforming operation and thermal stability of new porous metal supported tubular palladium composite membranes. Int J Hydrogen Energy 2013;38:8759-8771. doi:10.1016/j.ijhydene.2013.05.030.

[71] Gallucci F, van Sint Annaland M, Kuipers JAM. Autothermal Reforming of Methane with Integrated $\mathrm{CO}_{2}$ Capture in a Novel Fluidized Bed Membrane Reactor. Part 2 Comparison of Reactor Configurations. Top Catal 2008;51:146-157. doi:10.1007/s11244-008-9127-7. 